\title{
Administratörerna. Administration, kontroll och styrning vid svenska universitet och högskolor
}

\author{
Ola Agevall \& Gunnar Olofsson
}

SAMMANDRAG: Det svenska universitetssystemet har vuxit till att bli en omfattande och komplex institution. Expansionen har inte bara gällt antalet studenter, lärare och forskare utan också den administrativa ram de verkar inom och de personalkategorier som ingår däri. Men förhållandet mellan lärarkår och administratörer präglas inte sällan av misstro. I sin artikel vill Ola Agevall och Gunnar Olofsson tränga bortom parternas spontana föreställningsvärldar och se hur universitetsadministrationens sammansättning och omfång faktiskt förändrats under perioden 200I-20I8. De pekar på hur tillväxten av administratörer i huvudsak håller jämna steg med tillväxten av lärare och forskare. Däremot har administratörsgruppen ändrat karaktär - vilket kommer till uttryck i vilka delar av den som ökat respektive minskat, liksom vad som hänt med gruppens utbildningsnivå och könsfördelning. Det nya mönster som etableras under perioden kan förstås som en omställning av den administrativa personalens uppgifter till att tjäna ledningarnas strävan att styra och kontrollera verksamhetens effektivitet och produktivitet. En utveckling som kan förklara ökade spänningar i förhållande till universitetslärarprofessionen. En annan möjlig implikation kan vara att det ur administratörskåren växer fram en ny profession.

NYCKELORD: universitetsadministration; högskoleadministration; administratörer; lärare; forskare; profession; new public management.

PUBLICERINGSHISTORIK: Originalpublicering.

OLA AGEVALL är professor i sociologi vid Linnéuniversitetet.

E-POSTADRESS: ola.agevall@lnu.se

GUNNAR OLOFSSON är professor emeritus i sociologi vid Linnéuniversitetet.

E-POSTADRESS: gunnar.olofsson@lnu.se

FÖRSLAG PÅ KÄLLANGIVELSE:

Agevall, Ola \& Gunnar Olofsson (2020) "Administratörerna. Administration, kontroll och styrning vid svenska universitet och högskolor", i Arkiv. Tidskrift för sambällsanalys, nr I2, s. 7-59.

DOI: https://doi.org/I0.13068/2000-6217.I2.I

(C) Författarna/Arkiv förlag \& tidskrift 2020 (publicerad Is maj 2020)

Artikeln distribueras enligt en upphovsrättslicens från Creative Commons: Erkännande-Ickekommersiell-IngaBearbetningar 3.o Unported, som medger fri ickekommersiell användning och spridning i oförändrat skick så länge källan anges. 
Arkiv. Tidskrift för samhällsanalys är en sakkunniggranskad vetenskaplig tidskrift för samhällsvetenskap och historia. Samtliga artiklar publiceras fritt tillgängliga på:

$$
\text { www.tidskriftenarkiv.se }
$$

Beständig länk, DOI: https://doi.org/IO.I3068/2000-62I7

Den här artikeln finns tillgänglig i följande format:

PDF: via beständig länk, DoI: https://doi.org/IO.I3068/2000-6217.I2.I

TRYCK: ingår i bokutgåva av numret, ISBN: 978 9I 79243388

Grafisk utformning och sidnumrering är identisk i pdf och tryck.

Samtliga artiklar i nr I2 (2020) nås via beständig länk, DOI: https://doi.org/IO.I3068/2000-62I7.I2

Arkiv. Tidskrift för samhällsanalys

ISSN: 2000-62I7 (för elektronisk resurs)

ISSN: 2000-6225 (för tryckta nummer)

ges ut av

Stiftelsen Arkiv för främjande och spridning av samhällsvetenskaplig och historisk forskning

genom

Arkiv förlag \& tidskrift

Box 1559

SE-22I OI Lund

BESÖK: L Gråbrödersg 3 c, ipg

TEL: 046-I3 3920

ARKIV FÖRLAG: arkiv@arkiv.nu·www.arkiv.nu

TIDSKRIFTEN ARKIV: red@tidskriftenarkiv.se.www.tidskriftenarkiv.se

ANSVARIg UTGIVARE \& CHEFREDAKTÖR: Sven Hort

Administrativ Redaktör: David Lindberg

Redaktörer: Paavo Bergman, Per Dannefjord, Lisa Kings,

Zhanna Kravchenko, Anna-Maria Sarstrand Marekovic 


\title{
Administratörerna. Administration, kontroll och styrning vid svenska universitet och högskolor
}

\author{
OLA AGEVALL \& GUNNAR OLOFSSON
}

\section{Inledning och bakgrund}

I960-talet och tillkomsten av den moderna universitetsförvaltningen

Sedan millennieskiftet tilldrar sig universitetsadministrationen och dess

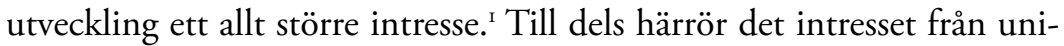
versitetsvärldens olika parter och inre kamper. Precis som andra yrkesgrupper och professionella grupper söker universitetslärare tolka och bevaka sin position i en föränderlig omvärld. ${ }^{2}$ Hit hör den universitetsadministrativa ram de verkar inom, och deras intryck av hur denna förändras i nutid. Till den akademiska professionens självbild hör i dag ofta en föreställning om att den bekostar och är trängd av en växande administrativ överbyggnad.

En andra källa till intresse för universitetsadministrationen berör en annan aspekt av professionernas sociologi. Håller universitetsadministrationen på att formeras till en egen profession? I det amerikanska samman-

I. Artikeln är en delstudie inom forskningsprojektet Svensk högre utbildning: finansiering, organisering, rekrytering, utfall I950-2020 (SHEFOE) (VR 2016-04746). En tidigare version presenterades i arbetsgruppen "Work, Organizations and Professions" under Sociologdagarna i Lund den 7-9 mars 2018.

2. I projektet Kunskapssamhällets bärare. En studie av professionernas historiska framväxt och nutida betydelse i dagens Sverige (VR 20IO-I457) analyserade vi vad de nya modellerna för styrning och ledning inom universitet och högskolor innebar för universitetslärarna. I det arbetet väcktes frågor om den administrativa personalens omfång och sammansättning. 
hanget är de redan organiserade i den professionella sammanslutningens form. Kommer något liknande att ske i Europa och i Sverige? Och vad innebär det i sin tur för universiteten och deras lärarkår?

Det finns därför starka utbildnings- och professionssociologiska skäl att undersöka hur den administrativa personalen vid svenska universitet och högskolor har utvecklats efter millennieskiftet. Universitetsadministrationen har sociologisk relevans både som professionsomgivning och som eventuell profession i vardande.

Syftet i vår artikel är att skildra hur universitetsadministrationens sammansättning och omfång förändrats under perioden 200I-20I8. I förlängningen är det vår förhoppning att undersökningen både kan tjäna som korrektiv till parternas spontana föreställningsvärldar och utgöra underlag för tolkningen av varför, var och hur dessa ståndpunkter och åsiktsbrytningar uppstår. En närmare precisering av syftet följer i avsnitt 2 nedan.

För att kunna analysera utvecklingen under den sista knappa tjugoårsperioden är det dock nödvändigt att utsträcka perspektivet och kort skildra den moderna universitetsadministrationens genes och efterföljande omvandlingar.

Grunden till det universitets- och högskolesystem vi har i dag lades under 1960-talet. ${ }^{3}$ Antalet studenter ökade dramatiskt, främst vid de filosofiska fakulteterna. Universitet och högskolor expanderade kraftigt. De gamla universiteten byggde ut filialer med start 1967. Nya slags lärartjänster tillkom (universitetslektorer och universitetsadjunkter). Universitetslektorer började tillsättas från 1958 och antalet ökade starkt under i96o-talet.

Deltidsanställda studenter, i form av amanuenser och assistenter, bistod undervisningen genom att leda övningar, laborationer och fältarbeten av olika slag. När antalet studenter ökade fick institutionerna automatiskt mer resurser så att de kunde anställa fler lärare, assistenter och amanuenser. Denna "automatik" fungerade under hela i96o-talet. Grunden lades också för en ny och mer formaliserad typ av forskarutbildning med ett stort inslag av kurser. Den gamla licentiatexamen omformades till den nya doktorsexamen genom beslut 1969.

3. Se Agevall \& Olofsson 2019 a. 
Även universitetens administration omvandlades och fick sin moderna form vid denna tid. 1960-talets rationella omorganisering av universitetens lärarkår och den samtidiga expansionen av antalet studenter ackompanjerades och möjliggjordes av en utbyggnad och modernisering av universitetens och högskolornas administrativa apparat. Fram till 1960talet var det i statsverkspropositionen och i riksdagen som enskilda detaljer i universitetens budget avgjordes, inklusive frågor om "huruvida den och den institutionen borde tilldelas en tjänst som vaktmästare, kontorsbiträde, ekonomibiträde etc.”" ${ }^{4}$ Detta system var nu under förändring.

Särskilda medel hade sedan tidigt 1960-tal avsatts i statsbudgeten för att öka det administrativa stödet till universiteten och deras fakulteter och institutioner. Men framför allt kom det centraliserade beslutsfattandet om enskildheter att ersättas av en mekanism för medelstilldelning, vilken i sin tur fordrade en administrativ apparat för att kalibrera verksamheten, det vill säga att registrera och hantera sådan information som behövdes för allokeringen av resurser.

Universitetsutredningen 1955 (U 55) drog upp riktlinjerna för en genomgripande modernisering av det svenska universitetssystemet. Den publicerade en rad betänkanden och förslag fram till 1963, inklusive förslag på hur universiteten och särskilt då deras ämnesinstitutioner skulle byggas upp och administreras. Man insåg att den pågående expansionen ställde stora krav på administrativa insatser från institutionernas ledning, främst på de olika ämnenas professorer vilket innebar

att professorers och laboratorers tid i viss utsträckning måste ägnas åt administrativa göromål, men självklart är, att denna tidsåtgång kan begränsas utan men för forskning och undervisning, genom att administrativa resurser ställes till institutionernas förfogande och genom en rationell arbetsfördelning inom dessa mellan å ena sidan den forskande personalen och å den andra olika slag av personal med administrativa arbetsuppgifter. ${ }^{5}$

Statskontoret gav i en bilaga till I955 års universitetsutredning förslag till hur lärares och forskares administrativa arbetsbörda skulle kunna rationaliseras och lättas.

4. Hjerdt-Goscinski, Nilsson \& Norman 1978, s. 289.

5. SOU i963:9, s. 64 . 
Vissa uppgifter skulle lyftas upp från institutionsnivån, genom en centralisering av ekonomi- och personalförvaltning. Det gällde exempelvis arbetsledningen för "tekniker, vaktmästare, biträden och annan personal på 'underhållssidan' inom en läroanstalt". Statskontoret föreslog också inrättandet av nya befattningar inom de större ämnesinstitutionerna - underprefekt och institutionssekreterare. Underprefekt kunde exempelvis vara

en universitetslektor med nedsättning i undervisningsskyldigheten som ett slags studierektor leder den lägre undervisningen. ${ }^{6}$

Förslagen att rationalisera det administrativa arbetet inom universiteten tog sig alltså tre olika former. För det första en centralisering av vissa uppgifter till nivåerna ovanför institutionsnivån, för det andra en förstärkning av det administrativa stödet på institutionsnivån (genom att bland annat anställa institutionssekreterare) och för det tredje att viktiga administrativa uppgifter skulle kunna utföras som del av en lärares tjänst, som exempelvis när en universitetslektor fick sin undervisningsskyldighet nedsatt för att fylla rollen som studierektor. Dessa tre modeller för att hantera det expanderande universitetssystemets växande administrativa uppgifter kom att forma universitetens och högskolornas förvaltningar under lång tid.

Inte minst kom institutionssekreterarna att spela en viktig roll som stöd för lärarna och för institutionernas funktionssätt. Betyg skulle föras in i register, lokaler skulle bokas, manus skulle renskrivas, besked skulle skickas till studenterna. Räknebiträden - en del var arkivarbetare kunde därtill bistå vid exempelvis stansning av hålkort och tidskrävande beräkningar med hjälp av Facits räknesnurror utifrån data som lärare och forskare samlat in.

Syftet med att bygga ut det administrativa stödet var att lärare och forskare skulle kunna lägga mer av sin arbetstid på att undervisa och forska. En väl fungerande administration var, då som nu, en viktig förutsättning för att en expanderande och komplex arbetsorganisation ska fungera.

6. SOU I963:IO, s. I6I. 


\section{Ändrad styrning - ökad självständighet}

En grundläggande förändring i den högre utbildningens organisation inträffade i och med de nya villkor som kom att gälla från och med mitten av 1990-talet.7 Successivt ökade de olika enheternas självständighet. Deras ledningar (styrelserna och rektorerna) fick ökade möjligheter att leda "sina" universitet och högskolor och kunde fördela medel på ett friare sätt. De kunde nu ställa om sin akademiska organisation (indelningen i fakulteter, institutioner, centrum med mera) och inte minst anpassa sina förvaltningar för att bättre passa till den nya, mer självständiga roll som enheterna fick, och för att genomföra de förändringar som rektorerna ville åstadkomma. Det blev än mer uttalat efter den så kallade autonomireformen 2009 som gav rektorer och styrelser ett vidgat manöverutrymme.

Efter hand kom universitetens och högskolornas förvaltningsorganisation att förändras på ett genomgripande sätt. Vi vill knyta den förändringen till de olika enheternas mera självständiga och oberoende villkor och till de lokala ledningarnas - och därmed "rektors" - ökade roll i ledningen, styrningen och den interna organiseringen av "deras" respektive enheter. Det är den förändringen som ger ramen för expansion och förändring av den administrativa personalens arbetsfunktioner.

Vi vill i denna artikel visa

- vilka yrkesgrupper som har ökat i antal under 2000-talet

- vad som skett med den administrativa personalens utbildningsnivå och dess könsfördelning

- hur gränsdragningen mellan de uppgifter som utförs av personal vid kärn- respektive stödverksamheterna ändras i dagens högskolesystem

- och diskutera om det ur administratörskåren växer fram en ny profession.

\section{Personalen vid universitet och högskolor 200I-20I8}

Inom universiteten, fackhögskolorna och de regionala högskolorna finns det flera yrkesgrupper utöver universitetslärarkåren. Tabell I nedan redovisar antalet helårsanställda vid universitet och högskolor i Sverige år 2001 och 2018.

7. Se till exempel Agevall \& Olofsson 20I9b. 
ARKIV | NR I2

Tabell I. Högskolans personal år 2001 och 2018 (helårsanställda)

\begin{tabular}{|c|c|c|c|c|}
\hline \multirow[b]{2}{*}{ Tjänstekategori } & \multirow{2}{*}{$\begin{array}{c}\text { Antal } \\
200 I \\
\end{array}$} & \multirow{2}{*}{$\begin{array}{c}\text { Antal } \\
2018 \\
\end{array}$} & \multicolumn{2}{|c|}{ Ökning/minskning } \\
\hline & & & $i$ antal & iprocent \\
\hline Professorer & 3269 & $5 \mathrm{I} 4 \mathrm{I}$ & I 872 & 57 \\
\hline Lektorer & 5715 & 9 I IO & 3395 & 59 \\
\hline Meriteringsanställningar & 995 & 3729 & 2734 & 275 \\
\hline Adjunkter & 6458 & 4907 & $-\mathrm{I} 55 \mathrm{I}$ & -24 \\
\hline Lärarkåren totalt & I6 437 & 22887 & 6450 & 39 \\
\hline AFU med doktorsexamen ${ }^{a}$ & I 96 I & 3436 & I 475 & 75 \\
\hline AFU utan doktorsexamen & 3446 & 4512 & I 066 & $3 \mathrm{I}$ \\
\hline Doktorander & 8 I 66 & I $2262^{b}$ & 4096 & 50 \\
\hline Bibliotekspersonal & I 443 & I I 70 & -273 & -19 \\
\hline Administrativ personal & 8632 & I 2337 & 3705 & 43 \\
\hline Teknisk personal & 7579 & 6568 & -I OI I & -13 \\
\hline Arvodister & I 557 & 762 & -795 & $-5 \mathrm{I}$ \\
\hline Totalt antal & $4922 I$ & 63933 & 14712 & 30 \\
\hline
\end{tabular}

a. AFU står för "Annan forskande och undervisande personal".

b. Totalt I6 86I individer.

Källa: UKÄ, Universitet och högskolor. Årsrapport 2019.

Tillsammans utgör grupperna administrativ, teknisk och bibliotekspersonal det så kallade verksamhetsstödet. År 2018 utgjorde dessa personalgrupper 39 procent av det totala antalet anställda vid universitet och högskolor. Dessa tre grupper var i det närmaste lika stor som lärarkåren, vars fyra grupper tillsammans utgjorde 44 procent av de anställda.

\section{Den administrativa personalen i fokus}

I denna artikel ska vi se närmare på den administrativa personalen, en central del av "verksamhetsstödet". Här återfinns stora yrkesgrupper med yrkestitlar som administratör, sekreterare, kommunikatör, ekonom, 
controller, utredare med flera. Den tekniska personalen ${ }^{8}$ och bibliotekspersonalen som också ingår i verksamhetsstödet faller därmed utanför vår studie.

Artikelns fokus är hur den administrativa personalens omfång, sammansättning, funktioner och utbildningsnivå såg ut 2018 och hur den förändrats sedan 200I. ${ }^{9}$

\section{Problem, frågeställningar och disposition}

Universitetens och högskolornas administrativa personal har ökat sedan år 200I, samtidigt som den har fått en delvis annan karaktär. Nya grupper av anställda har tillkommit medan andra har minskat i omfattning. Hur skall den förändringen förklaras?

Vi vill här pröva antagandet att nya avdelningar och funktioner växer fram inom universitets- och högskoleförvaltningarna som ett svar på de nya krav och uppgifter som ställs på högskolesektorn från riksdagens och regeringens sida.

Föreställningen att den administrativa personalens ökning drivs fram av byråkratins inre självförstärkande natur finns i många universitetslärares spontana tänkande. ${ }^{10}$ Universitetens och högskolornas administrativa personal har förändrats i sin sammansättning under 2000-talet men inte ökat som andel av lärosätenas personal. Vissa yrkesgrupper ökar medan andra minskar. Det beror, som vi skall visa i avsnitt 6 och

8. Den tekniska personalen har en stor spännvidd - däri ryms såväl datatekniker och driftchefer som vaktmästare och städpersonal. Delar av den tekniska personalen organiseras inte bara i SACO och TCO utan också i LO. Lokalvårdare och vaktmästare å ena sidan, tekniker och forskningsingenjörer å den andra är stora grupper i denna personalkategori.

9. Tidsperioden är vald utifrån att det finns detaljerad och jämförbar statistik om högskolesektorns personal från och med år 200I.

IO. Vi har ofta hört den förklaringen yttras av kollegor. Det poängterar hur viktigt det är att hålla universitetslärarnas vardagstänkande och spontana filosofi kring "byråkratin" i schack när vi analyserar universitetens omvandling. Jämför här den uppfordran till "epistemologisk vaksamhet" som poängteras av Pierre Bourdieu m.fl. i Le métier de sociologue (I968, i engelsk översättning som The Craft of Sociology, I99I) och analysen av vetenskapsmännens "spontana filosofi" i Louis Althussers Philosophie et philosophie spontanée des savants (1974, i dansk översättning som Filosofi, ideologi og videnskap, 1975). 
7 nedan, i huvudsak på att lärosätena och deras ledningar ställts inför nya uppgifter och att expansionen av nya styrnings- och kontrollfunktioner satt tydliga spår i den administrativa personalens uppgifter och yrkessammansättning.

Vi avgränsar oss också mot de argument som ser ökningen av den administrativa personalen som oproblematisk och självklar, som en funktionell nödvändighet. En aktuell och omfattande statlig utredning hävdar att stödverksamhetens tillväxt är ett självklart uttryck för den förvaltning som universiteten "behöver ha". Utredaren ägnar ett fåtal korta avsnitt åt verksamhetsstödet, dess omfattning, sammansättning och effektivitet. ${ }^{\text {II }}$ Man ser inte administrationens omfattning som ett problem - eftersom den finns är den också nödvändig. ${ }^{\text {I2 }}$

Givet den utredningens uppdrag och fokus på ledning och styrning av lärosätena så poängteras särskilt förvaltningspersonalens roll som stöd och instrument för ledningens förmåga att styra och kontrollera verksamheten. Den synpunkten kommer vi att ta fasta på och titta närmare på den ökande roll som delar av den administrativa personalen har fått $\mathrm{i}$ att "styra och kontrollera".

$\mathrm{Vi}$ vill pröva tesen att universitetsförvaltningarnas omstöpning kan begripas som en anpassning till universitetens och högskolornas nya situation, där nya typer av styrnings- och budgetmodeller och en tydlig ökning av ledningarnas makt har kommit att prägla universitets och högskolors villkor.

De sätt varpå dessa nya omgivningsbetingelser slår igenom i de olika enheternas administrativa apparater kan vi analysera genom att undersöka den administrativa personalens förändrade yrkessammansättning och utbildningsnivå. Analysen av dessa förändringar sker utifrån vår övergripande tes att alltmer av den administrativa personalens uppgifter blir att tjäna ledningens strävan att styra och kontrollera verksamhetens effektivitet, inklusive produktiviteten i kärnverksamheten hos lärare och forskare.

II. SOU 20I5:92, s. II8-I20, s. $269 \mathrm{ff}$.

I2. "Eftersom lärosätenas uppdrag är utbildning och forskning så saknar all verksamhet som inte på något sätt bidrar till detta uppdrag ett syfte" (ibid., s. 279). Utredningen tycks här parafrasera den formulering som Voltaire lägger i Candides mun. 
Artikeln är disponerad på följande sätt: Avsnitt 3 ger en historisk bakgrund till universitetsadministrationens utveckling sedan I990-talet. Därefter följer en kort diskussion om de administrativa funktionerna vid lärosätena. Det femte avsnittet diskuterar den pågående omfördelningen av administrativa uppgifter mellan universitetens lärarkår och administratörerna.

I avsnitt 6 beskriver vi förändringen i den administrativa personalens yrkessammansättning under åren 200I till och med 20I8. Avsitt 7 och 8 visar förändringarna i dess utbildningsnivå respektive könsfördelning. Därefter följer ett avsnitt där vi diskuterar om universitetsadministratörernas ledande skikt kan ses som en profession i vardande.

Till slut ställer vi frågan om de förändringar i den administrativa personalen som vi kartlagt och analyserat kan förstås som en förskjutning i kårens uppgifter till att i ökad utsträckning bistå lärosätenas ledningar i deras styrning och kontroll av verksamheten.

\section{Universitetens och högskolornas förändrade situation}

\section{Styrning, budget och konkurrens}

Som en följd av de nya budget- och styrningsmodeller som infördes 1993 har universitet och högskolor satts i en situation där de skall konkurrera med varandra om studenter (genom att bland annat utveckla attraktiva utbildningsprogram), om lärare och forskare (genom att erbjuda goda villkor ifråga om lön och arbetsvillkor) och inte minst om ekonomiska resurser, särskilt då forskningsmedel. Denna explicita konkurrenssituation har ökat ledningarnas strävan att styra lärares och forskares prestationer så att de blir till än större nytta för lärosätet (till exempel genom att de skaffar sig nya forskningsanslag). Nya administrativa enheter och anställning av nya slags tjänstemän har tillkommit för att rusta de enskilda universiteten och högskolorna för denna konkurrens. Likaså har det administrativa maskineriet utvecklats och förfinats genom en expansion av de kontroll- och styrorgan som verkar centralt inom den högre utbildningen. 


\section{Kontroll- och styrmaskineriets förändring på central nivå}

Den högre utbildningens väldiga expansion - såväl av antalet studenter, lärare och annan personal som av dess totala kostnader - har ackompanjerats av en utbyggnad av styrande, kontrollerande och stödjande myndigheter på central nivå, ovanför de enskilda universiteteten och högskolorna. Som alla statliga myndigheter är universiteten i blickfånget för "sitt departement", för Ekonomistyrningsverket (ESV) samt för Riksrevisionen och Statskontoret.

Två av Utbildningsdepartementets sju enheter är riktade mot den högre utbildningen, den Forskningspolitiska enheten med ca 2I tjänstemän och Universitets- och högskoleenheten (26 tjänstemän), en betydande andel av departementets totalt 238 anställda. ${ }^{13}$

Mellan departementet och de cirka 6o lärosätena finns en rad myndigheter och verk med styrande, kontrollerande och stödjande funktioner. ${ }^{14}$ De viktigaste är Universitetskanslersämbetet (UKÄ) med 97 anställda ${ }^{15}$ och Universitets- och högskolerådet (UHR) med 326 anställda. ${ }^{16}$ Grovt sett är skillnaden mellan dem att UHR:s fokus är service och samordning till stöd för lärosätena medan UKÄ har funktionen att styra, kontrollera och utvärdera deras verksamhet. Den helt övervägande delen av UKÄ:s personal har högskoleexamen och 20 av dem har doktorsexamen. ${ }^{17}$

Service- och stödfunktionerna är tydligt länkade till styr-, kontrolloch utvärderingsfunktionerna. Ta till exempel de system som registrerar studieprestationer (LADOK), hanterar blivande studenters meriter vid antagning $(\mathrm{NyA})$ och registrerar forskarnas vetenskapliga prestationer

13. Uppgiften avser år 2016 och är hämtad från Regeringskansliets hemsida den 5 februari 20I8. Uppgifterna om antalet anställda vid Forskningspolitiska enheten och Universitets- och högskoleenheten har vi fått från departementet och avser år 2019.

I4. Jfr framställningen i UKÄ:s årsrapporter av de olika organ och myndigheter som i dag finns, exempelvis Överklagandenämnden. Hit bör vi även räkna sådana styr- och kontrollmyndigheter som övervakar all statlig verksamhet, som exempelvis ESV.

I5. Enligt UKÄ:s årsredovisning för 2019 var antal årsarbetskrafter det året 86.

I6. Siffror från UHR:s årsredovisning 2019 (medelantalet anställda var 326 vilket motsvarar 282 årsarbetskrafter).

I7. Data om utbildningsnivå i JÄMIX 20I6. Uppgift om antalet disputerade i brev från UKÄ (Kerstin Jonsson) den I8 februari 2018. 
(DiVA). De ger service till stöd för lärosätena. ${ }^{18}$ Samtidigt utgör de kontrollens och utvärderingens infrastruktur. Med hjälp av data som tillhandahålls genom dessa system kan centrala och lokala beslutsfattare utvärdera och styra sektorns olika verksamheter.

\section{Kontroll- och styrmaskineriets förändring på lokal nivå}

En andra nivå utgörs av de universitetsinterna styr- och kontrollsystemen. De består av rektorsämbetet och den centrala administrativa ledningen, i dagligt tal "rektor", och av den lokala ekonomistyrningen på enhets- och fakultetsnivå. Inte minst har nya funktioner av typen planeringsenheter tillkommit. För styrning och kontroll på det lokala planet spelar de ekonomutbildade tjänstemännen en ökande och därtill strategisk roll.

På denna andra, lokala nivå har man också, i en slags symbios med UKÄ:s innehållsliga styrningsintention, tillskapat egna lokala enheter som tar sig an styrningen av utbildningarnas inriktning och utformning och kontrollen av deras kvalitet. Det sker genom egna utredningsoch utvärderingsenheter, genom att bygga upp enheter för pedagogisk utveckling och så vidare. ${ }^{19}$ Denna typ av kognitiv styrning sker genom utredningar, produktion av styr- och modelldokument för både kurser och hela program och genom utbildning av lärare. Här har inte minst (disputerade) pedagoger kommit att spela en viktig roll.

Den symbiotiska relationen mellan central och lokal nivå tar sig även andra utryck. Belysande för hur de länkas samman är den kontroll och styrning som sker genom olika modeller för selektiv resurstilldelning. Ett exempel är de modeller som utarbetats för att tillföra medel för forskning (eller utvecklingsarbete i vissa fall) till olika enheter i universitetssystemet, och till olika forskargrupper och individer, exempelvis till så kallade

I8. Dessa system utvecklades från början av I990-talet. LADOK förvaltades ursprungligen av Verket för högskoleservice men ligger i dag under ett konsortium vars medlemmar är trettiosju av landets lärosäten samt CSN. För drift och utveckling av DiVA ansvarar Avdelningen för biblioteksstöd och Enheten för digital publicering vid Uppsala universitet. UHR är systemansvarigt för $\mathrm{NyA}$, men också för systemet Diver som kopplar samman LADOK, NyA och DiVA.

I9. Se t.ex. Friberg 20I5, Stigmar 2009 och en innehållsrik antologi, Ryegård, Olsson \& Apelgren 2010. 
excellenscentrum. Denna typ av styrning praktiseras via de centrala vetenskapliga forskningsråden genom fördelning av forskningsmedel till lärosäten och forskargrupper. ${ }^{20}$ Det sker även sådana "excellens"-satsningar inom universitet och högskolor, ibland även på fakultetsnivå.

Denna styrning verkar genom den selektiva premieringen. Tilldelningen sker ibland genom kollegial och samhällelig bedömning av forskningsansökningars kvalitet och relevans. De organ som fördelar sådana medel finns på såväl EU-nivå (de europeiska forskningsråden och EU:s olika ramprogram) som på nationell nivå (forskningsråden, stora stiftelser $^{21}$ med mera) eller på lokal nivå. Detta resursflöde utgör en avgörande del ( 56 procent år 20I8) av universitets- och högskolesektorns intäkter för forskning. ${ }^{22}$

\section{Den nya situationens effekter inom högskolan: frän kollegial ledning till managementkonform styrning}

Universitetens och högskolornas förvaltningsapparat var historiskt uppbyggd för att passa in i den gängse typen av statlig myndighet, som därtill hade en speciell kollegial komponent. Den skulle nu, efter de radikala förändringar som genomfördes i början av 1990-talet, anpassas till att fungera i den nya situation där lärosäten konkurrerar om attraktiva utbildningar, studenter, skickliga lärare, produktiva forskare, statens bevågenhet och inte minst forskningsmedel från forskningsråd och andra finansiärer.

I denna process har universitetsledningarna "fått" mer av en företagsledarroll (än av myndighetsledning) för att bättre kunna hantera förändringar i verksamhetens förutsättningar. Det passiva och neutrala verbet "få" i meningen här ovan kan ersättas med andra ord på en skala som löper från "reaktiv anpassning" till "aktivt agerande" - de kan motvilligt "tvingas till", de "anpassar sig" (mer eller mindre entusiastiskt) eller så "griper de aktivt de nya möjligheterna”. På samma sätt som en generaldirektör för Televerket hade en annan uppgift än vad en vd för Telia fick, ändrades villkoren och uppgifterna för ledningarna vid universitet och

20. Se exempelvis VR 20I4.

2I. Bland annat Riksbankens Jubileumsfond, Wallenbergstiftelserna och inte minst de stiftelser som övertog löntagarfondernas medel.

22. UKÄ, Universitet och högskolor. Årsrapport 20I9, tabell 34. 
högskolor genom den serie av reformer som omformat hela sektorn sedan I990-talet.

I linje med dessa förändringar har högskolesektorns förvaltningsapparater och dess personal genomgått dramatiska förändringar och helt nya avdelningar och enheter har inrättats. Den administrativa personalens roll, inriktning och uppgifter förändras i och genom dessa anpassningsprocesser. Detta kommer till mätbara uttryck i förändringen av administratörernas arbetsuppgifter, utbildningsbakgrund och tjänstetitlar.

Men det är inte bara nya funktioner och krav som universiteten ska hantera. En genomgående trend under de sista sextio åren har också varit en successivt ökad styrning och kontroll av hur den högre utbildningen ska fungera, och av hur utbildningar ska formuleras, kontrolleras och utvärderas, såväl ekonomiskt som innehållsligt.

\section{Den administrativa personalens funktioner och dess förändring över tid}

Historiskt sett har den administrativa personalen haft uppgifter av främst två olika slag. Det var dels fråga om de myndighetsbärande funktionerna, förkroppsligade i de akademitjänstemän och handläggare som skulle hantera universitetsförvaltningens samordnande, ledande och inte minst dess juridiska och ekonomiska uppgifter, dels de tjänstemän som fungerade som kanslipersonal, kontorister, institutionssekreterare med mera och som därigenom administrativt biträdde såväl ledningen som forskarna och lärarna.

De olika personalgrupperna inom verksamhetsstödet flankerar universitetens och högskolornas kärna, den undervisande och forskande personalen. De fullgör centrala funktioner inom universitetens och högskolornas komplexa arbetsdelning. Tanken bakom den utbyggnad av det administrativa stödet vid universiteten, som ackompanjerade deras expansion från slutet av 1950-talet, var att göra det möjligt för lärare och forskare att koncentrera sitt arbete till universitetets kärnuppgifter, undervisning och forskning.

I många avseenden påminde universitetens organisation om hur andra statliga myndigheter och verk var organiserade. Det gällde exempelvis 
tjänstenomenklaturen i administrationen med dess byråassistenter, byråsekreterare, byrådirektörer, byråchefer och avdelningsdirektörer.

Under senare decennier har nya funktioner och därmed nya grupper av anställda tillkommit inom universitets- och högskolesystemets enheter. En del av dessa är främst avsedda som stöd för ledningarna. Det gäller för de nya och starkt växande informationsavdelningarna, och yrkesgrupper som (strategiska) kommunikatörer och informatörer. Planeringsenheterna har kompletterats med utrednings- och utvärderingsavdelningar liksom med universitetspedagogiska enheter.

Exemplet med universitetspedagogiska enheter är illustrativt, i så måtto som dessa redan inledningsvis blev sammankopplade med de utvärderings- och resursfrågor som ledningarna hade att hantera. I den resursutredning som beledsagade 1993 års universitetsreform hette det exempelvis:

Universitetet åtar sig att utöver den utvärderingsverksamhet som Utvärderingssekretariatet bedriver för egen del och i samverkan med andra universitet och högskolor vidta följande åtgärder för att säkra kvaliteten i grundutbildningen

- systematiskt bedöma lärarnas undervisningsmeriter,

- för samtliga lärare som önskar det, inkludera universitetspedagogisk utbildning i respektive institutions bemanningsplan,

- genomföra självvärdering årligen vid minst en sjättedel av institutionerna.

Om universitetet inte uppfyller dessa åtaganden skall takbeloppet för det sista budgetåret minskas med en procent. ${ }^{23}$

De konkreta benämningarna på dessa olika enheter kan skifta men de återfinns på i princip alla lärosäten. Personaladministratörerna har blivit fler, personalavdelningarna större, och nya beteckningar på tjänstemännen (HR-konsult och andra HR-benämnda yrken) signalerar en ny inriktning.

Universitet och högskolor har både tilldelats nya uppgifter och själva tagit på sig andra som en konsekvens av ett vidgat uppdrag. Lärare och studenter reser ut från landet och samtidigt kommer många studenter och forskare till de olika lärosätena från andra länder. Detta har lett till att

23. SOU I993:3, s. 48 . 
man inrättat avdelningar eller kontor för internationalisering. Detsamma gäller för samverkan, forskningsservice, EU-kontor med mera.

Nya arbetsuppgifter har vidare tillkommit för att hantera och stödja studenterna, både med deras studier (exempelvis språkverkstäder) och för att förbereda dem för en kommande arbetsmarknad. Studie- och karriärvägledning har blivit viktiga inslag i högskolornas vardag och antalet studievägledare har ökat över tid.

Även fakulteternas administration har vuxit och förändrats. En ny kategori, utbildningsledare (som ofta har doktorsexamen), finns nu på åtskilliga fakulteter och lärosäten.

\section{Omfördelning av arbetsuppgifter mellan lärare och administratörer}

\section{Mer administration för lärare och forskare?}

Andelen administratörer i universitetens personal har totalt sett inte ökat påtagligt under de sista 15-20 åren, även om det finns en synlig ökning under senare år. Samtidigt har lärare och forskare fått ägna en större del av sin arbetstid åt administrativa uppgifter enligt en undersökning av Åmossa (2018). Det har skett både genom att vissa arbetsuppgifter knuffats tillbaka till den akademiska personalen och genom att de ställts inför utvidgade krav på dokumentation av undervisning, examination och kursplanering.

Att en del administrativa uppgifter återförts till lärarna anförs i en utredning om universitetens ledningsproblem (SOU 2015:92) som en möjlig förklaring till varför andelen administratörer inte har ökat. Vissa arbetsuppgifter hade under universitetens expansion under 1900-talets senare halva spjälkats av från universitetslärarna och i stället blivit arbetsuppgifter för den administrativa personalen. I samband med att många administrativa uppgifter senare kommit att utföras med hjälp av datorer och med stöd av olika datasystem har uppgifter som tidigare utförts av särskilda administratörer, främst sekreterare på olika nivåer, nu åter hamnat på lärares och forskares bord. Exempelvis gäller detta schemaläggning, lokalbokning, inrapportering av studieresultat till dokumentations- 
systemet för studenternas prestationer (LADOK), bokning av resor, hantering av reseräkningar med mera. Den utvecklingen är inte en självklar och rationell lösning. Den ska i stället ses som resultatet av en kamp om vem som ska råda över goda och mindre goda arbetsuppgifter. Tekniska förändringar leder ofta till att den rådande uppgiftsfördelningen mellan olika grupper ändras. Det sker, och har skett, på många andra delar av arbetsmarknaden.

När detaljhandeln lades om från att kunderna betjänades av expediter, som både vägde upp specerier i påsar och plockade ner varor från hyllorna, till introduktionen av de nya snabbköpen, med dess färdigförpackade varor, så innebar det att kunderna övertog en betydande del av expediternas tidigare arbete. Snabbköpen blev möjliga genom en rad nya förpackningstekniker och en därtill knuten ändring i butikernas arkitektur. Detta medförde en ändrad arbetsdelning mellan kunderna och handelns anställda. Ett annat exempel är att många enkla bankärenden, som att till exempel betala räkningar, successivt har överförts från bankens anställda till kunderna genom att internetbankerna lanserats. Bankerna behöver mindre personal och kunderna kan sköta sina bankärenden på tider som passar dem. Kunderna utför nu själva mera av bankväsendets rutinuppgifter.

Denna kombination av datorisering, rationalisering och förflyttning av rutinuppgifter finns också inom statsförvaltningen och den är påtagligt närvarande inom universitet och högskolor.

\section{Universitetslärarnas arbetsuppgifter}

Lärare vid universitet och högskolor har i princip tre olika slag av arbetsuppgifter: de undervisar, forskar och administrerar. ${ }^{24}$ I det danska universitetssystemet talade man länge om UFA-normen. Den angav hur proportionerna för innehållet i en tjänst som adjunkt, lektor eller professor normalt skulle fördelas. Undervisning $(\mathrm{U})$ stod för 50 procent, forskning (F) stod för 40 procent och administration (A) för Io procent.

\footnotetext{
24. Nya uppgifter kan tillföras lärarkåren - den "tredje uppgiften" är en sådan. Med det menas en aktiv relation till världen utanför universiteten själva - forskningsförmedling med mera. Det intressanta med benämningen "tredje uppgiften" är att de administrativa sysslorna då tycks försvinna som egen kategori.
} 
Vilken omfattning och vilket innehåll har de svenska universitetslärarnas tjänster i dag och vilket utrymme tar de administrativa sysslorna? Och vad kan vi säga om dessa sysslors utveckling över tid - ägnas de mera tid, är det fråga om nya inslag? Jämför vi med den gamla danska UFA-normens fasta proportioner mellan uppgiftstyper så framträder komplexiteten i dagens svenska system. I det förra är den enskildes undervisningsvolym konstant och lika för alla; i det senare är proportionerna mellan uppgiftstyperna variabla och individualiserade.

Arbetsinnehållets individualisering har varit ett viktigt inslag i ledningars ambition att styra sina verksamheter. Genom selektiv premiering ska forskare och lärare ges rätt incitament och förmås att producera rätt saker. Den variabilitet som individualiseringen medför ger samtidigt upphov till särskilda administrativa utmaningar. På institutionsnivå ska tjänsteplanerare och ekonomer matcha undervisnings- och andra verksamhetsbehov med de enskilda lärarnas forskningstid, vilken kan variera från person till person och från år till år eller från månad till månad. Det förutsätter en kontinuerlig bevakning, inte bara av bemanningen till kurser utan också av de ekonomiska effekterna av att lärarlöner belastar den ena eller den andra kostnadsbäraren. Det förutsätter också uppbyggnaden av system av indikatorer med vars hjälp man kan mäta prestationer, system för att registrera dem, samt personalgrupper som kan fatta beslut om och förvalta dessa system och datamängder.

Som illustration till det ovanstående kan anföras tillkomsten av den så kallade SUHF-modellen i mitten av oo-talet. ${ }^{25}$ Lärosätenas ledningar var angelägna om att bygga upp sådana administrativa apparater som de ansåg att en ny situation och nya uppgifter krävde. Men därmed behövde man hantera frågan hur lärosätenas samlade kostnader skulle fördelas på de verksamheter som genererade intäkter, såsom undervisning, forskning och andra uppdrag. Samtidigt började externa forskningsfinansiärer sätta gränser för hur mycket av de lärosätesgemensamma kostnaderna de var villiga att bidra till, i form av projektens overheadkostnader. Och eftersom externa medel blivit en allt viktigare del av lärosätenas ekonomi

25. Sveriges universitets- och högskoleförbund (SUHF) är ett samarbetsorgan mellan universitet och högskolor. Det bildades 1995. Se Agevall \& Olofsson 20I9b, s. II7-II9 för en beskrivning av dess uppkomst och uppgifter. 
var det angeläget att finna lösningar som var godtagbara för båda parter. Det föranledde rektorskonferensen SUHF att 2007 formulera och rekommendera en ny redovisningsmodell för fördelning av indirekta kostnader, vilken i sin tur har generaliserats och genererat nya administrativa arrangemang och uppgifter:

Modellen kräver tydliga ansvars-, besluts-, och delegationsordningar vid varje högskola. Tydliga regler och riktlinjer måste fastställas för kalkylering, planering, löpande redovisning och uppföljning. [...] Modellen kräver att ett ändamålsenligt tidrapporteringssystem införs vid varje högskola, som visar hur de anställda i stort fördelar sin faktiska arbetstid på olika kostnadsbärare och verksamhetsgrenar. Utredaren rekommenderar att individuell tidrapportering tillämpas. Den innebär att de anställda anger faktisk nedlagd tid, som sedan rapporteras in till redovisningssystemet vecko- eller månadsvis. ${ }^{26}$

Planering och uppföljning i ett sådant system ger upphov till fler och mer kvalificerade planerings-, kalibrerings- och redovisningsuppgifter som ska hanteras på universitetsadministrationens olika nivåer. Vi återkommer till detta i kommande avsnitt i diskussionen av hur de administratörskategorier utvecklats som hanterar lärosätenas ekonomifunktioner.

Här vill vi emellertid peka på vad detta innebär för lärar- och forskargruppens relation till administrativa sysslor, och för gränssnittet mellan dem och administratörsgruppen. För att åskådliggöra detta är det instruktivt att införa en distinktion mellan "uppgiftstid" och "klocktid". ${ }^{27}$

Klocktid är den tidsregim som traditionellt har gällt för högskolornas administrativa personal. Det är stämpelklockans tid, hämtad från en tayloristisk modell för arbetsorganisering, där anställda stämplar in vid arbetsdagens början och stämplar ut vid dess slut. När arbetsdagen är slut är arbetet slut. Uppgiftstid är en tidsregim av annat slag. Det finns en uppgift, ett pensum, som den anställde ska lösa inom ramen för sin anställning. Hur arbetet fördelas över dygnets timmar står det den anställde fritt att själv avgöra. Uppgiftstid har traditionellt präglat

26. Rapport av utredaren Ulla-Kari Fällman (2007, s. 8). Den modell för tidsrapportering som i utredningen ansågs nödvändig har bara delvis och gradvis realiserats vid landets lärosäten, men med hjälp av nya inhyrda system (t.ex. i form av tjänsteplaneringssystemet Retendo) kan de eventuellt vara på väg att realiseras fullt ut.

27. Se Olofsson 2006. 
universitetens lärare och forskare. Det är den vi ser i den danska UFAnormen. De tio procent som där avsattes till administration var en schablon som svarade mot ett bestämt antal timmar, och inom dess ram förväntades lärarna och forskarna utföra allt sådant som räknades som administrativa sysslor.

Vad betyder då kombinationen av individualiserat arbetsinnehåll och finfördelat redovisningssystem för lärarnas och forskarnas tidsregim? Och vad innebär det mer specifikt för deras förhållande till administrativa sysslor? Till att börja med innebär det att schabloner, uppgiftstidens yttre skal, kan få mycket olika resultat för enskilda lärare. Schabloner gynnar dem vilkas arbetsuppgifter i mindre utsträckning medför reella administrativa plikter, och missgynnar dem som utför ett administrativt arbete som fordrar större tid och möda än vad de får ersättning för. Uppgiftstidsregimen förlorar på så sätt i självklarhet, och kan ifrågasättas av såväl rättvise- som effektivitetsskäl. Alternativet är då att göra avsteg från den rena uppgiftstidsregimen så att varje administrativ syssla definieras och tilldelas en specifik mängd timmar. Även denna fördelningsmekanism är, som vi strax ska se, behäftad med svårigheter. Dessförinnan ska vi dock beskriva hur hanteringen och fördelningen av administrativ tid konkret kan gå till, och illustrera detta med uppgifter från två institutioner.

Formellt ska, enligt arbetstidsavtalen, det administrativa arbetet bokföras som del av tjänstens innehåll när prefekter och studierektorer i dag gör upp de individuella timplanerna för institutionens adjunkter, lektorer, postdoktorer och professorer.

(I) Administrationsuppgifterna kan finansieras via institutions-, fakultetseller universitetsbudgetarna men de syns alla i de anställdas timplaner på institutionsnivå.

(2) De kan tilldelas som en timschablon för alla som är lärare/forskare på en institution. ${ }^{28}$

28. Vid Sociologiska institutionen i Lund får alla lärare/forskare 44 timmar per år för att delta i institutionsmöten, internat med mera. Vid Linnéuniversitetets institution för samhällsstudier är motsvarande tariff 85 timmar. 
(3) Och/eller som ett bestämt antal timmar (eller procent av tjänst) för särskilda uppgifter. Det gäller för uppgifter som att vara prefekt, studierektor, programansvarig, kursansvarig med mera.

(4) Ofta är därtill administrativa sysslor inbokade i den tilldelning en lärare erhåller för att ge en kurs - och då är undervisning, förberedelse, examination, inrapportering av resultat i LADOK, löpande studentkontakt, lokalbokning och så vidare inräknade i den tiden, det vill säga det antal timmar som en lärare får räkna som sin arbetstid. ${ }^{29}$

En del av de administrativa ledningsfunktionerna är formaliserade som särskilda (hel- eller deltids)tjänster - prefekt, studierektor, dekan etc. De kan också ge särskilda lönetillägg. Andra uppgifter, som att vara kursansvarig, programansvarig, ordförande i olika kommittéer med mera ger avtryck i respektive tjänsts timfördelning. Dessa synliga delar av den institutionsnära administrationen bärs upp av universitetslärarna och utgör en markant del av deras formaliserade arbetstid. Den utgjorde för en liten institution (Institutionen för samhällsstudier) vid ett mindre lärosäte (Linnéuniversitetet) I3 procent (för uppgifter av typ 3 ovan) och 5 procent (av typ 2) av lärarkårens samlade arbetstid. Vid en motsvarande men större institution vid ett större universitet (Sociologiska institutionen i Lund) utgjorde den I5,5 procent (typ 3) och 2,5 procent (typ 2).

Som framgår redan av denna redovisning kan allmänna schabloner i olika proportioner blandas med specificerad uppgiftstid för enskilda befattningar och med uppgiftstid knuten till kursgivning, kommittéer och andra uppgifter. Det finns skäl att tro att det finns stora variationer mellan institutioner, fakulteter och lärosäten - såväl ifråga om vilken tid som avsätts för lärares administration som ifråga om hur den finansieras, genom vilka mekanismer den fördelas, och hur detta slår på olika personalkategorier. Till detta kommer ytterligare en viktig typ av variation, nämligen mängden mer eller mindre specificerade konkreta uppgifter som i varierande grad förväntas rymmas inom respektive administrativt

29. En delkurs på 7,5 poäng i sociologisk teori på andra terminen ger vid Lunds universitet läraren totalt Ioo timmar. Uppgift från lektor Magnus Karlsson den I4 september 2019. 
uppdrag. Frågan om vilken tid lärarna och forskarna lägger på administration kan på så sätt betyda två olika saker: å ena sidan den tid som i timfördelningar bokförs som administration, och som den anställde alltså fått betalt för i timmar, å andra sidan den tid som faktiskt åtgår när den anställde utför dessa administrativa sysslor.

För den enskilde kan en given administrativ uppgift på så sätt framstå som toxisk eller välkommen. Toxiska uppgifter är sådana som inte ges timmar, eller inte ges tillräckligt med timmar för att utföra sysslan. Välkomna administrativa uppgifter är sådana som givits en generös timtilldelning i förhållande till den verkliga tidsåtgången. I ett system med individualiserat arbetsinnehåll erbjuder sådana välkomna administrativa uppgifter lättnad i arbetet för den som uppbär dem, och ger tid över som kan läggas på annat. Detta är viktigt om man ska förstå varför det $\mathrm{i}$ lärargruppen kan finnas en beredvillighet att acceptera tillkomsten och expansionen av (vissa) administrativa uppgifter.

Så länge de timmar som avsätts för lärarnas administration finansieras av institutionens egna medel är detta ett nollsummespel. Varje timme som ges till person $\mathrm{A}$ för sysslan $\mathrm{x}$ måste tas från sysslan $\mathrm{y}$, som utförs av A själv eller av kollegan B. När finansieringen kommer till institutionen från fakultetsnivån blir den ett nollsummespel bara på den överordnade nivån, medan det inom den institution som kan tillvälla sig uppgiften är ett plussummespel och därmed en impuls att bejaka den administrativa uppgift som avlönas.

När lärare och forskare känner frustration över en större administrativ börda är det sannolikt de (upplevda) toxiska administrativa uppgifterna som avses i första hand. I själva verket är uppgiftstiden, lärarnas och forskarnas traditionella tidsregim, mycket sårbar i detta hänseende. Uppgiftstiden är en öppen säck. Om enskilda moment förskjuts, förändras, tillkommer eller knuffas tillbaka till läraren, så ingår också de i lärarens pensum. Arbetets förutsättningar och konkreta innehåll förändras men uppgiften måste alltjämt lösas. I en sådan situation finns två olika sätt att reagera.

För det första kan man kräva att de uppgifter som måste utföras också ska avlönas med tid. Arbetets alla delmoment måste då identifieras, avgränsas och "prissättas" med timmar. Det är detsamma som att 
göra avsteg från uppgiftstidens regim. Det system som då uppstår går inte i riktning mot en renodlad tayloristisk klocktidsregim, utan är snarare att jämföra med ett hemindustriellt system, där varje "timavlönad" uppgift är ett arbetsstycke som den anställde ska hantera och där lärarens och forskarens samlade arbetstid består av en stor mängd sådana arbetsstycken. Detta sätt att reagera på toxiska arbetsuppgifter sammanfaller väl med det detaljerade timredovisningssystem som lärosätena har försvurit sig till och som ledningarna gärna vill använda i styrningen och kontrollen av verksamheten. Varje lärartjänst består då av många kostnadsställen, vilka alla idealt ska bära sina egna kostnader. Att arbetstagarens reaktion här sammanfaller med arbetsgivarens önskemål och med logiken i redovisningssystemen talar för att den fortsatta utvecklingen kommer att gå i denna riktning.

Som lösning på problemet med toxiska arbetsuppgifter har det dock begränsningar. Avgränsningen och timsättningen av arbetets delmoment är med nödvändighet ungefärlig och byggd på skattningar, och behöver inte resultera i att enskilda uppgifter blir mindre toxiska. Med ett arbetsinnehåll som är individualiserat och varierar från person till person kan finfördelningen av arbetsmoment slå mycket olika för olika personer och grupper, och det på ett mer oöverskådligt sätt. Så länge det är institutionens egna medel som finansierar uppgifterna tillförs heller inga nya medel. Varje timsatt arbetsstycke som hanteras av någon minskar mängden arbetstimmar som står till förfogande för andra uppgifter och personer. Men till detta kommer att finfördelningen av administrativa arbetsmoment inte rår på situationer där arbetets konkreta innehåll förändras genom att nya moment tillkommer eller knuffas tillbaka till lärare och forskare. Nya arbetsmoment måste, åtminstone inledningsvis, falla mellan stolarna i systemet av timsatta uppgifter.

För det andra kan man reagera genom att vilja stoppa det flöde av nya och förändrade uppgifter som hamnar i uppgiftstidens öppna säck. Men förskjutningar i gamla administrativa arbetsuppgifter, och tillkommande nya sådana, kan vara svåra att värja sig mot. Det hänger samman med gränssnittet mellan lärar- och forskargruppen och administratörsgruppen. Mellan den anställda administrativa personalen och kärnverksamhetens lärare och forskare finns det kommunicerande kärl där uppgifter 
kan flyta fram och tillbaka. Det är särskilt två aspekter av denna relation som vi vill lyfta fram. Det ena är vad som händer när nya tekniska och tekniskt-administrativa system introduceras. I sådana situationer kan arbetsdelningen mellan kategorierna stöpas om. Det andra är vad som sker i och med att den administrativa personalens sammansättning och utbildningsnivå förändras och, som en följd av detta, hur deras yrkesambitioner och beredskap att utföra olika uppgifter då förändras.

\section{Uppgifter på drift? Teknisk-administrativ förändring, nya aspirationer och uppgiftsföden}

En tes vi vill hävda är att det alltid sker - eller kan ske - en omförhandling av olika gruppers arbetsuppgifter i samband med teknisk förändring. Aktuella exempel på sådan förändring är digitaliseringen och införandet av nya administrativa system och rutiner. Under 2000-talet har en rad datoriserade system byggts ut vid universitet och högskolor för att hantera lärares examination av studenter, för lokalbokning, för reseräkningar och så vidare. Det rör sig om så kallade lärplattformar (ibland flera olika på samma lärosäte), systemet för registrering av studenternas examina (LADOK), system för att boka lokaler, hur lärare ska upptäcka plagiat och rapportera in individuella studieplaner. System för personaladministration och ekonomiadministration har också byggts ut, ändrats och förnyats.

I dag har en allt större del av det arbete som krävs för att rapportera in och hantera uppgifter i dessa olika system blivit en del av lärarnas arbetstid. Några år tillbaka i tiden låg en större andel av denna typ av rapportering i händerna på för dessa uppgifter särskilt anställda administratörer, hos institutionssekreterare, ekonomihandläggare och hos personalavdelningen.

Utbyggnaden av ett stort antal datoriserade registrerings- och inrapporteringssystem har alltså lett till en ändrad arbetsdelning mellan lärare och forskare å ena sidan och professionella administratörer å den andra. Successivt har en större andel av detta arbete i praktiken blivit en del av lärarnas och forskarnas plikter. Det har i de flesta fall inte lett till att dessa grupper fått en ökad tilldelning av timmar för att utföra dessa arbetsuppgifter; de hör till det slags administrativa sysslor som av lärarna uppfattas 
som toxiska. Men överflyttningen av dessa administrativa (rutin)uppgifter till lärargruppen har inte lett till att antalet administratörer har minskat. Det har däremot, vilket vi visar i avsnitt 6 nedan, lett till att den administrativa personalen fått nya arbetsuppgifter. ${ }^{30}$

Det som vid en första anblick ser ut som en lyckad rationalisering av det administrativa uppgiftsfödet inom universitet och högskolor leder till minskad effektivitet. Det beror på att den i detta avseende amatöristiska lärargruppen fått hantera tämligen komplicerade registreringssystem vilka hade kunnat skötas mer effektivt av specialiserade administratörer.

När sådana arbetsuppgifter som en gång kanske utgjorde det mesta av en administratörs arbetsuppgifter nu förs tillbaka till ett antal lektorer och professorer blir resultatet en särskild slags paradox. Det ser ut som en betydande rationalisering i och med att en person (eller en personalkategori) frigörs från rutinbetonade arbetsuppgifter.

Det arbetet fördelas i stället på ett större antal personer och upptar givetvis en mycket mindre andel av varje enskild persons arbetstid än den gjort hos den som tidigare utfört uppgifterna. Vi får på det viset ett organisatoriskt osynliggörande av denna samlade arbetstid. Den blir osynlig eftersom den för var och en bara tar en mindre del av arbetstiden. Denna uppsplittring och förflyttning av administrativa arbetsuppgifter gör inte att de försvinner, utan tvärtom till att de totalt sett tar mer samlad tid i anspråk. Till det kommer att den tid de tar i anspråk kostar mer eftersom lektorer och professorer är bättre betalda än de administratörer som tidigare hanterat uppgifterna.

Föreställningen att arbetstiden som åtgår blir försumbar när den delas upp på många gör att den här typen av återförande av tidigare specialiserade arbetsuppgifter är något som inte bara förekommer inom universitets- och högskolevärlden. Denna rationaliseringsillusion har påverkat arbetsfördelningen mellan olika yrkesgrupper på en rad andra arbetsplatser och inom olika organisationer, inte minst vid de stora sjukhusen. Antalet läkarsekreterare har minskat radikalt utifrån idén att läkarna själva inte bara ska diktera in resultatet av sitt möte med en patient, sina observationer och diagnoser, och sedan få det utskrivet. Läkaren

30. Se Åmossa 2018. 
ska sedan själv korrigera felen och missförstånden i den text som dikteringsprogrammet producerar. Tillsammans med många andra skriv- och dokumentationsuppgifter som nu åligger en behandlande läkare på ett sjukhus, tar dessa administrativa uppgifter så pass mycket extra tid, jämfört med tidigare, att hen får mindre tid att möta patienter. Det kan röra sig om flera besök per dag som nu inte blir av. ${ }^{3 \mathrm{I}}$

Inom universitetens värld har den snabba datoriseringen av det administrativa arbetet lett till en omfördelning av många konkreta arbetsuppgifter. Vem skall utföra de datoriserade formerna för dessa sysslor - specialiserade administratörer eller lärare och forskare med andra huvuduppgifter? Svaret på den frågan handlar inte bara om att organisera en rationell och tekniskt effektiv arbetsdelning mellan de olika yrkesgrupperna. Häri finns också en kamp om arbetsdelningens sociala och inte minst genusmässiga sidor som kommer till uttryck i en statuskamp mellan grupperna. Varför skall (kvinnliga) sekreterare serva (manliga) professorer med att skriva rent manus, kopiera artiklar och undervisningsmaterial åt lärarna med mera? När vi ser överflyttningen av registreringsuppgifter av skilda slag från lärosätenas administrativa personal till lärargruppen är effekten tämligen entydig, det vill säga en tillbakaknuffning.

Omfördelningar mellan olika gruppers arbetsuppgifter kan emellertid ha andra orsaker. En mekanism som kan verka i den riktningen är när enskilda och grupper av anställda aktivt strävar efter att göra sig kvitt arbetsuppgifter som de anser tråkiga och triviala.

I denna form torde kampen om att slippa rutinuppgifter bli mer påtaglig ju högre utbildning administratörsgruppen har..$^{32}$ Denna önskan från den administrativa personalens sida hänger samman med att allt fler av dem har en akademisk examen och ser sig som akademiker, och i det avseendet likställda med lärargruppen, och att de därför har krav

3I. Intervju med läkare på Skånes universitetssjukhus 6 mars 2020.

32. En anekdot kan få illustrera den mekanism vi har i åtanke. Ett nytt datasystem för att registrera personalens reseräkningar infördes vid dåvarande Växjö universitet. Då flyttades det (okvalificerade) registreringsarbetet över från personalavdelningen till lärargruppen med följande motivering från en personalkonsult: "Vi vill ha mera utvecklande arbetsuppgifter", det vill säga man ville inte längre behöva hjälpa lärare och forskare med sådana rutinuppgifter de själva kunde klara av. 
på karriär och intressanta arbetsuppgifter. Den administrativa personalens utbildningsnivå, och hur den utvecklats sedan millennieskiftet, står i fokus i avsnitt sju nedan. Dessförinnan ska vi skildra förändringarna i administratörskårens sammansättning under samma tid, och utveckla våra förslag på hur man ska förstå dem.

\section{Administratörskårens förändring under 2000-talet}

I vår presentation och analys av hur administratörsgruppen har förändrats under 2000-talet använder vi dels sådan statistik som redovisats $i$ form av rapporter och meddelanden från SCB, dels opublicerade data som vi fått eller beställt från samma myndighet. Alla tabeller som redovisar data om yrkestitlar kommer från de råtabeller vi fått från $\mathrm{SCB}$ vid olika tidpunkter. Vi fick först tillgång till sådana data från åren 200I och 2004 och sedan för 2014 och 20I6. Sommaren 2019 beställde vi motsvarande data för åren 2010 och 20I8. I denna statistik redovisas all personal utifrån den yrkestitel de har, oberoende av om personerna arbetar heltid eller deltid. Vi använder källhänvisningen "råtabeller SCB” i dessa fal. I övriga fall anger vi den källa varifrån vi hämtat data.

Vi kommer främst att analysera uppgifter om yrkesnomenklaturens förändring under perioden 200I-20I8. Utifrån dessa data kan vi inte följa individers karriärbanor och deras skiftande yrkesbeteckningar. Vi kommer däremot att redovisa och diskutera ökningar och minskningar av olika tjänstetitlar. I många fall är förändringarna dramatiska. Vi lyfter i vår redovisning fram sådana förändringar i yrkesnomenklaturen som säger något viktigt om universitets- och högskolesystemets förändrade villkor under 2000-talet.

Från och med 1993, och än tydligare under 2000-talet, har administrationen vid universitet och högskolor förändrats från en traditionell, regelstyrd statlig förvaltningsapparat till något annat. De olika enheterna ska nu som vi sett konkurrera om studenter och studieplatser, om lärare, forskare och forskningsanslag.

Denna nya konkurrenssituation har lett till att ledningarna vid universitet och högskolor önskat öka sin förmåga att leda och styra den underliggande verksamheten. Det har skett på flera olika sätt. Utred- 
nings-, planerings- och kommunikationsavdelningar har tillkommit eller ökat i storlek och kompetens. Arbetet på utförande nivåer styrs genom att deras resurser påverkas av de prestationer, exempelvis examinationsfrekvens och antal publicerade artiklar, som de anställda vid olika institutioner har åstadkommit.

\section{Proportionell ökning - ändrad sammansättning}

Antalet administratörer vid universitet och högskolor ökade under perioden 200 I-20I8 med 62 procent (se tabell 2) i riket som helhet. Ökningen av antalet individer är klart större än ökningen av antalet helårsanställda i denna kategori (se tabell I på sidan I2 ovan).

\section{Tabell 2. Administrativ personal (antal individer och tjänstetitlar)} vid universitet och högskolor från år 2001 till 2018 (råtabeller SCB)

\begin{tabular}{lcc} 
Ar & Administratörer & Tjänstetitlar \\
\hline $200 \mathrm{I}$ & 9627 & 470 \\
2004 & I0 917 & 597 \\
2010 & I2 486 & 788 \\
2014 & I3 083 & 852 \\
2016 & I3 265 & 840 \\
2018 & I5 577 & 911 \\
\hline
\end{tabular}

Administratörskåren har ändrats i sin sammansättning. En första indikation är att antalet tjänstetitlar har ökat dramatiskt, med 93 procent. Många starkt specialiserade yrkestitlar har tillkommit. Gamla tjänstetitlar har ersatts av nya samtidigt som helt nya tjänstetyper har tillkommit. ${ }^{33}$ Många av dessa yrkestitlar bärs emellertid upp av bara en eller ett fåtal personer. En mera relevant bild av förändringen inom administratörsgruppen ges i tabell 3 nedan som redovisar de vanligaste yrkestitlarna vid periodens början och slut. Tabellen visar hur omfattande förändringen av yrkestitlarna var mellan de båda åren, med markanta ökningar och minskningar av antalet personer i många olika tjänstekategorier.

33. En del av ökningen kan ha förhandlingstekniska skäl eftersom en ny titel kan vara ett argument för att höja individers, eller en mindre grupps, löner. 
Tabell 3. De vanligaste tjänstetitlarna inom den administrativa personalen 2001 och 2018 (rätabeller SCB)

\begin{tabular}{|c|c|c|c|}
\hline Tjänstetitel & Antal 200I & Tjänstetitel & Antal 2018 \\
\hline Institutionssekreterare & 966 & Administratör & 899 \\
\hline Assistent & 577 & Ekonom & 640 \\
\hline Byrådirektör & 567 & Handläggare & 617 \\
\hline Byråsekreterare förste & $39 \mathrm{I}$ & Kommunikatör & 607 \\
\hline Högskolesekreterare & 320 & Timavlönad & 555 \\
\hline Intendent & 3 I 8 & Tjänsteman & 519 \\
\hline Administratör & 3 I 2 & Utbildningsadministratör & 475 \\
\hline Avdelningsdirektör & 308 & Studievägledare & $4 \mathrm{I} 3$ \\
\hline Studievägledare & $29 \mathrm{I}$ & Samordnare & 358 \\
\hline Sekreterare & 262 & Ekonomiadministratör & 336 \\
\hline Ekonomiadministratör & I9I & Koordinator & 260 \\
\hline Byråassistent & 162 & Studieadministratör & 256 \\
\hline Byråsekreterare & 156 & Administrativ chef & 230 \\
\hline Informatör & 146 & Utbildningshandläggare & 210 \\
\hline Ekonomi-personaladministratör & 136 & Enhetschef & 199 \\
\hline Skrivningsvakt & 132 & Assistent & I 74 \\
\hline Ekonom & 130 & Avdelningschef & I7I \\
\hline Kursadministratör & I 28 & Kursadministratör & 164 \\
\hline Studieadministratör & I 20 & Controller & I 47 \\
\hline Utbildningsledare & 99 & Projektkoordinator & I 47 \\
\hline Utbildningsadministratör & 98 & Forskningsassistent & I 43 \\
\hline Ekonomihandlägg amu & 93 & Utredare & I 42 \\
\hline Löneadministratör & $9 \mathrm{I}$ & Projektsamordnare & I 27 \\
\hline Handläggare & 86 & Handläggare, kvalificerad & I 27 \\
\hline Telefonist & 84 & Institutionsadministratör & 125 \\
\hline Projektsekreterare & 84 & Tentamensvakt & I 2 I \\
\hline Föreläsare med mera & 82 & Forskningssamordnare & II 7 \\
\hline Ekonomiassistent & 80 & Antagningshandläggare & II 7 \\
\hline Administrativ chef & 78 & Personalhandläggare & I 13 \\
\hline Receptionist & 68 & $\mathrm{Hr}$-specialist & I I I \\
\hline Universitetssekreterare & 67 & Receptionist & 107 \\
\hline Utbildningssekreterare & 60 & Personaladministratör & 105 \\
\hline Tjänsteman & 58 & Fakultetsadministratör & IO4 \\
\hline Föreståndare & 56 & Utbildningsledare & IOI \\
\hline Administrativ assistent & 53 & Studie- och karriärvägledare & IOO \\
\hline Kanslichef & 52 & Statistiker & 95 \\
\hline Koordinator & $5 \mathrm{I}$ & Internationell koordinator & 94 \\
\hline Assistent/kansliskrivare & 51 & Ekonomihandlägg amu & 93 \\
\hline Personaladministratör & 51 & Utbildningssamordnare & $9 \mathrm{I}$ \\
\hline Personalhandläggare & 50 & Forskningsadministratör & 90 \\
\hline
\end{tabular}




\section{Byrådirektören som försvann}

År 200I fanns de typiska statstjänstemannatitlarna i stor utsträckning kvar inom universitetens och högskolornas administration. De härbärgerade de hierarkiskt ordnade handläggande tjänstemännen, från byråassistenter, via byråsekreterare, byrådirektörer och avdelningsdirektörer till byråchefer. Tjänstetitlarna var knuta till bestämda löneintervall (lönegrader och inom dessa ett antal löneklasser) och denna kodifierade vertikala kommandostruktur var regel inom statsförvaltningen.

De äldre tjänstemannatitlarna ersattes vid mitten av det nya seklets första decennium av dels preciserade funktions- och yrkestitlar som speglade arbetsuppgifternas konkreta innehåll (av typen ekonom, kommunikatör med flera) och dels av nya, mer generella tjänstetitlar (administratör, tjänsteman med flera). De här förändringarna påverkar både en given administratörs anställning och arbetsuppgifter (vad som exempelvis ska ske vid arbetsbrist) och inte minst löneplaceringen. Utvecklingen är en del av den av- och omreglering som skett gällande statstjänstemännens anställningsvillkor.

Tabell 4. Förändringen $i$ antalet traditionella statstjänstemannatitlar mellan 2001 och 2018 (ràtabeller SCB)

\begin{tabular}{|c|c|c|c|c|c|c|}
\hline Tjänstetitel & $200 I$ & 2004 & 2010 & 2014 & 2016 & 2018 \\
\hline Byråchef & I7 & 8 & 4 & I & o & $\mathrm{o}$ \\
\hline Avdelningsdirektör & 308 & 248 & 87 & 28 & I 8 & I 2 \\
\hline Byrådirektör & 567 & 490 & 2 I I & 90 & 65 & 46 \\
\hline Byråsekreterare, förste & $39 I$ & 276 & 87 & 27 & I 4 & 8 \\
\hline Byråsekreterare & 156 & I IO & 42 & I 4 & 9 & 9 \\
\hline Byråassistent & 162 & I I 5 & 25 & 33 & $\mathrm{I}$ & $\mathrm{I}$ \\
\hline Summa & I $60 I$ & I 247 & 456 & 193 & 107 & 76 \\
\hline
\end{tabular}

\section{Minskande och ökande kategorier}

FÄRRE SEKRETERARE. Det är inte bara statens traditionella byråkratititlar som har minskat radikalt i antal. Det gäller också för många grupper av "sekreterare", inklusive gruppen "institutionssekreterare". Sekreterarna med specificerande prefix har däremot blivit fler (till exempel forskningssekreterare och fakultetssekreterare). Samtidigt har antalet 
anställda med yrkestitlar som innehåller ordet "administratör" ökat (se tabell 6). Den här förskjutningen rymmer sannolikt både rena omdöpningar och en förändring av arbetsuppgifter (och lön).

Tabell 5. Minskningen av antalet "sekreterare" och "assistenter" mellan 2001 och 2018 (råtabeller SCB)

\begin{tabular}{lrrrrrr} 
Tjänstetitel & 2001 & 2004 & 2010 & 2014 & 2016 & 2018 \\
\hline Sekreterare & 262 & I 5 I & 97 & 53 & 43 & 37 \\
Institutionssekreterare & 966 & 834 & 290 & 88 & 59 & 65 \\
Högskolesekreterare & 320 & 308 & 42 & $2 \mathrm{I}$ & 8 & 7 \\
Assistent & 577 & $4 \mathrm{II}$ & 208 & 48 & 63 & I79 \\
Assistent med förled $^{\mathrm{a}}$ & I 060 & 855 & 446 & 342 & $348^{\mathrm{b}}$ & $5 \mathrm{I} 3$ \\
\hline
\end{tabular}

a. Inklusive byråassistent och ekonomiassistent.

b. Härav var det år 201696 forskningsassistenter. År 2001 och 2004 redovisades ingen forskningsassistent i kategorin administrativ personal.

Minskningen av antalet sekreterare och institutionssekreterare är mycket markant. Det torde den vara också i de flesta universitets och högskolors reella vardag. Till en viss del har det skett en överflyttning av sekreterarnas arbetsuppgifterna till kategorin administratörer, samtidigt som denna grupp i större utsträckning i dag återfinns på nivåer ovanför institutionerna. Den klassiska servicefunktion som utfördes av de olika sekreterargrupperna i relation till lärare och forskare på institutionsnivå har i stor utsträckning eliminerats och de arbetsuppgifter de tidigare hanterade har delvis förts över till lärare och forskare. (Jämför diskussionen ovan i avsnitt 5.)

ÖKANDE ANTAL ADMINISTRATÖRER MED GENERELLA YRKESTITLAR. Det har skett en markant ökning av flera generella yrkestitlar som "tjänsteman", "administratör", "samordnare" och "koordinator" bland administratörerna vid universitet och högskolor. Vi redovisar detta i tabellerna 6 och 7. Personer med allmänna yrkestitlar kan lättare flyttas mellan olika arbetsuppgifter och avdelningar. I många fall har därtill en ny yrkestitel för exempelvis en sekreterare inneburit en förflyttning från institutionstill fakultetsnivå eller högre än så inom en högskola. 
Tabell 6. Ökningen av antalet "tjänstemän" och "administratörer" mellan 200I och 2018 (rätabeller SCB)

\begin{tabular}{lrrrrrr} 
Tjänstetitel & 200I & 2004 & 2010 & 2014 & 2016 & 2018 \\
\hline Tjänsteman & 58 & 2 I6 & 600 & 578 & 589 & 5 I9 \\
Administratör & 3 I 2 & 523 & 925 & I I 82 & I 278 & 899 \\
Administratör med förled & I 353 & I 739 & 2916 & 2910 & 3275 & 2954 \\
Administrativ i titeln & I 59 & 288 & 36 I & 460 & 468 & 500 \\
\hline
\end{tabular}

Tabell 7. Ökningen av antalet "samordnare" och "koordinatorer" mellan 2001 och 2018 (rätabeller SCB)

\begin{tabular}{lrrrrrr} 
Tjänstetitel & 2001 & 2004 & 2010 & 2014 & 2016 & 2018 \\
\hline Samordnare & 33 & 43 & I4I & I93 & 290 & 358 \\
Samordnare med förled & 57 & I47 & $3 \mathrm{I} 8$ & $7 \mathrm{I} 7$ & $7 \mathrm{IO}$ & 777 \\
Summa samordnare & 90 & 190 & 459 & 910 & 1000 & 1135 \\
Koordinator & $5 \mathrm{I}$ & 95 & 205 & $\mathrm{I} 97$ & $20 \mathrm{I}$ & 280 \\
Koordinator med förled & 57 & $\mathrm{IO}$ & 358 & $4 \mathrm{I} 8$ & 457 & 443 \\
Summa koordinatorer & 108 & 197 & 563 & 615 & 658 & 723 \\
Samverkans- som förled & 2 & 2 & $\mathrm{I} 3$ & 40 & $4 \mathrm{I}$ & $56^{\mathrm{a}}$ \\
\hline
\end{tabular}

a. Samverkanskoordinator var den största gruppen (3I).

"Samordning" och "koordinering" kan innebära samordning av olika enheter och aktörer inom en mer komplex administrativ struktur, med bland annat fler tillfälliga arbets- och projektgrupper. Det kan också vara fråga om uppgifter inom en större forskningsgrupp eller om samverkan med aktörer utanför högskolans ram.

\section{Nya yrkestitlar inom avgränsade grupper}

INFORMATÖRER OCH KOMMUNIKATÖRER. En specialiserad yrkesgrupp som snabbt har vuxit fram inom den administrativa personalen är informatörer och kommunikatörer (se tabell 8 nedan). Kommunikationsavdelningar har både lärosätesinterna uppgifter (ansvar för all webbpublicering, personalinformation, information till studenterna med mera) och ansvar för den utåtriktade marknadsföringen av lärosätet, 
dess forskning och utbildningar. Gruppernas expansion är i hög grad en effekt av lärosätenas reella och upplevda konkurrenssituation.

\section{Tabell 8. Antalet informatörer och kommunikatörer 200I-20I8 (rätabeller SCB)}

\begin{tabular}{lrrrrrr} 
Tjänstetitel & $200 I$ & 2004 & 2010 & 2014 & 2016 & 2018 \\
\hline Informatör & 67 & 230 & 334 & 238 & 184 & $9 \mathrm{I}$ \\
Kommunikatör & 0 & I & 34 & 335 & 475 & 637 \\
Information-, inkl. chef & 69 & $8 \mathrm{I}$ & $8 \mathrm{I}$ & 46 & $5 \mathrm{I}$ & 54 \\
\hline
\end{tabular}

Totalt sett var det en markant ökning av denna grupp: först av "informatörer" och sedan sker det en överväxling till yrkestiteln "kommunikatör".

FRÅN PERSONALSEKRETERARE TILL »HR-PARTNER«. År 2018 fanns det 318 personer som anges ha olika HR-yrken, en titeltyp som över huvud taget inte fanns representerad i förteckningen för åren 2001 och 2004. Då var i stället grupperna personalsekreterare och personalhandläggare vanligare (5I respektive 50 år 200I).

Bakom övergången från yrkestitlar av typen "personal-" till typen "HR-" ligger dels en ren omdöpning, dels att nya uppgifter har tillkommit. Därtill kommer att de akademiska utbildningar som är inriktade mot personalfrågor alltmer har kommit att använda sig av begreppet "human resources" ("humankapital") för att beteckna den kommande yrkesfunktionen. Totalt sett är ökningen av denna kategori markant.

Tabell 9. Förändring av tjänstetitlar inom personal- och HRavdelningarna 200I-20I8 (rätabeller SCB)

\begin{tabular}{lrrrrrr} 
Tjänstetitel & 2001 & 2004 & 2010 & 2014 & 2016 & 2018 \\
\hline Personal- & 356 & 450 & 492 & 518 & 496 & 482 \\
HR- & 0 & 0 & 7 & 45 & 173 & 318 \\
\hline
\end{tabular}

Not: Personal- och HR- anger alla tjänstetitlar där dessa ord är prefix. Den första förekomsten av titeltypen "HR-" är från år 2008. 
FRÅN STUDIEVÄGLEDARE TILL KARRIÄRCOACHER. Universitet och högskolor har tillskapat stödfunktioner för att bistå studenterna i deras val av studieinriktning men också för att hjälpa dem i deras studieförlopp. Det är i dag inte bara studievägledare som står till buds utan också karriärvägledare och -coacher.

Tabell Io. Antalet studievägledare och karriärcoacher 200I-20I8 (ràtabeller SCB)

\begin{tabular}{lrrrrrr} 
Tjänstetitel & $200 I$ & 2004 & 2010 & 2014 & 2016 & 2018 \\
\hline Studievägledare & 299 & 374 & 433 & $4 \mathrm{I} 6$ & 405 & $4 \mathrm{I} 3$ \\
Karriärvägledare, -coach & 2 & 4 & I6 & $8 \mathrm{I}$ & I0 I & I 22 \\
\hline
\end{tabular}

Den samlade ökningen inom dessa två grupper, från 301 till 535 anställda, kan ha sin förklaring i hur viktigt det är för de konkurrerande lärosätena att deras studenter etablerar sig på arbetsmarknaden. Att studenterna som tagit sin examen får (välbetalda) jobb är ett viktigt argument för att locka till sig nya studenter.

\section{Expansion av grupperna kvalificerade utredare och analytiker}

Under 2000-talet har alltmer personal rekryterats för att utföra kvalificerade uppgifter inom de lokala förvaltningsapparaterna. De återfinns vanligen i avdelningar som är nära knutna till ledningen, inom rektorskansliet eller i en särskild utredningsavdelning. En del av denna nya personal har titlar och kvalificerade arbetsuppgifter som utredare, analytiker och utvärderare.

Tabell II. Antalet analytiker, statistiker och utredare 200I-20I8 (rätabeller SCB)

\begin{tabular}{lrrrrrr} 
Tjänstetitel & $200 I$ & 2004 & $20 I 0$ & $20 I 4$ & $20 I 6$ & 2018 \\
\hline Analytiker $^{\mathrm{a}}$ & 2 & 2 & $\mathrm{I} 4$ & $4 \mathrm{I}$ & 52 & 69 \\
Statistiker & 26 & 45 & $8 \mathrm{I}$ & 63 & 68 & 95 \\
Utredare & $4 \mathrm{I}$ & 64 & $\mathrm{I} 9$ & $\mathrm{I} 27$ & $\mathrm{I} 29$ & $\mathrm{I} 46$ \\
\hline
\end{tabular}

a. Analytiker med förled räknas in. Från och med 20I4 är många av dem miljöanalytiker. 
De har till uppgift att bevaka förändringar i högskolans omgivning som kan påverka lärosätets situation, exempelvis ha överblick över de finansieringsmöjligheter som finns för både forskning och samverkan med näringsliv och myndigheter. De tar också fram underlag för ledningen så att den kan bedöma utbildningarnas förlopp, de anställdas trivsel och hälsa och hur det går för lärosätets studenter på arbetsmarknaden (genom studentundersökningar och alumnuppföljningar).

\section{Personal för styrning och kontroll - chefer och ekonomer}

CHEFSYRKENAS TILLVÄXT. Den detaljerade personalstatistiken tyder på att chefstätheten har ökat. Antalet chefer ökade mellan 200I och 2018 med I35 procent. En del av den ökningen kan bero på en omklassificering av yrkestitlar. Så har antalet "administrativa chefer" i det närmaste tredubblats mellan $200 \mathrm{I}$ och 2018 , från 78 till 230. En motsvarande chefsfunktion enligt den äldre titulaturen, "avdelningsdirektörer" ${ }^{34}$, minskade radikalt mellan 200I och 20I8, från 308 till endast I2 (se tabell 4 ovan).

\section{Tabell I2. Antalet chefer och direktörer 200I-20I8 (rätabeller SCB)}

\begin{tabular}{lrrrrrr} 
Tjänstetitel & $200 I$ & 2004 & 2010 & 2014 & 2016 & 2018 \\
\hline Chef i titeln $^{\mathrm{a}}$ & 525 & 7 I 2 & 8 I 8 & I 073 & I I06 & I 236 \\
Direktör i titeln $^{\mathrm{b}}$ & 35 & 57 & 62 & 48 & 48 & 57 \\
\hline
\end{tabular}

a. Ej chefssekreterare eller chefsassistent.

b. Exklusive byrå- och avdelningsdirektör, ej heller musikdirektör.

Det är rimligt att anta att den ökade chefstätheten ska förstås som en ökad styrning och kontroll av lärar- och forskargruppen. De allt fler cheferna kan till en viss del också vara resultatet av en ökning av chefstätheten inom förvaltningarnas inre organisation. Det kan handla om att skapa fler karriärvägar för lojala medarbetare.

FLER EKONOMER, FLER CONTROLLERS. Två andra, och snabbt växande yrkesgrupper ska förstås mot bakgrund av de krav som ställs på ekono-

34. Den titeln markerade i regel att innehavaren hade ett tydligt ansvarsområde och ofta en chefsroll. 
misk styrning, redovisning, uppföljning och planering i den konkurrenssituation som de lokala enheterna befinner sig i. Vi avser här ekonomer och controllers (styrekonomer).

År 2018 var antalet personer i ekonomyrken ganska stort, med 640 ekonomer och 237 controllers. Dessa yrkestitlar är förbehållna de som har en ekonomexamen på högskolenivå, vilket inte är fallet med yrken som ekonomihandläggare, löneadministratör med flera.

Antalet controllers har under perioden $200 \mathrm{I}$ till 2018 åttadubblats. Ekonomkåren som helhet har ökat i både antal (med en femdubbling av antalet "ekonomer") och i mängden av yrkestitlar. Den ökningen är i sin tur kopplad till den ökande betydelse som ekonomisk styrning och redovisning fătt inom högskolor och universitet.

"Intendent" är en äldre yrkestitel som bars av ekonomiansvariga, särskilt på institutionsnivå. Den gruppen har minskat i antal under 2000talet. Det är rimligt att anta att en del av dessa tjänster har döpts om till "ekonom". Det innebär att nettoökningen av gruppen ekonomer blir något lägre. Hur antalet personer med ekonomyrken har ökat mellan 200I och 2018 framgår av tabell $\mathrm{I} 3$.

\section{Tabell I3. Antalet ekonomer, controllers och intendenter} 200I-20I8 (råtabeller SCB)

\begin{tabular}{lrrrrrr} 
Tjänstetitel & $200 I$ & 2004 & 2010 & 2014 & 2016 & 2018 \\
\hline Ekonom (enbart) & I 30 & $22 \mathrm{I}$ & 378 & 475 & 524 & 640 \\
Controller & 26 & 37 & 74 & $\mathrm{I} 07$ & $\mathrm{I} 22$ & $\mathrm{I} 47$ \\
Controller med förled & 2 & 8 & 33 & 66 & 75 & 90 \\
Intendent & 318 & 290 & $\mathrm{I} 68$ & 103 & 89 & 79 \\
\hline Totalt & 476 & 556 & 653 & 751 & 810 & 956 \\
\hline
\end{tabular}

DET SAMLADE ANTALET EKONOMYRKEN 20I8. Tabellen ovan visar att antalet administratörer med enradiga yrkestitlar som "ekonom" och "controller" ökat kraftigt under 2000-talet. Vi har bearbetat 2018 års data och då tagit med alla de yrkestitlar som har ekonomanknytning, det vill säga titlar som har "ekonom" eller "controller" som för- eller efterled. Det visar sig då att det totala antalet som är engagerade som ekonomer 
i olika slags befattningar år 2018 var betydligt fler än i de ekonomyrken som kräver en akademisk examen, se tabell I4.

\section{Tabell I4. Samtliga anställda i ekonomyrken inom universitet och högskolors administration fördelade efter utbildningsniva år 2018 (råtabeller SCB)}

\begin{tabular}{lc} 
Utbildningsnivå & Antal \\
\hline Minst 3 år högskoleutbildning & 985 \\
Kortare högskoleutbildning & I 74 \\
Gymnasial utbildning $^{\mathrm{b}}$ & 255 \\
\hline Totalt & I 4I4 \\
\hline
\end{tabular}

a. Inklusive några forskarutbildade.

b. Inklusive några med grundskola.

\section{Sammanfattning av administratörskårens yrkesmässiga omdaning under 2000-talet}

I vår bearbetning av den detaljerade statistik som sedan 200 finns tillgänglig om alla tjänster vid universitet och högskolor har vi granskat hur den administrativa personalens yrkestitlar har förändrats. Vi har särskilt velat visa på de förändringar som kan länkas till de nya villkor som universitet och högskolor haft att anpassa sig till. De olika lärosätena har fått en större självständighet i hur de vill organisera sig internt, hur de vill lägga upp sin utbildning och vilka grupper av anställda de vill satsa på. Samtidigt ska de numera konkurrera om attraktiva utbildningsprogram, studenter, lärare och forskningsanslag. Denna av statsmakterna påbjudna autonomi har gett ledningarna ett vidgat handlingsutrymme men också större ansvar för det egna lärosätets utveckling. Den ökade autonomin i relation till Utbildningsdepartementet och sektorns myndigheter motsvaras inom lärosätena av en förskjutning uppåt av makt och inflytande till ledningsnivå ("rektor"). Det visar sig i några av de förändringar av den administrativa personalens sammansättning som vi har skildrat i detta avsnitt.

Lärosätenas förvaltningar ändrade karaktär under 2000-talets första decennium. Den traditionella statliga myndighetsstrukturen, med 
dess hierarkiskt uppbyggda tjänstetyper, har nu i huvudsak ersatts av en tjänstestruktur som är ordnad på ett mer flexibelt sätt. Byrådirektörens död gav liv åt snabbt expanderande tjänstekategorier av typen samordnare, tjänsteman, administratör, ekonom, controller, etc.

Kvalificerade tjänster, med titlar som analytiker, utredare, statistiker, har ökat i antal. De är normalt knutna till lärosätesledningarna i egna enheter eller som en del av rektorskanslierna. Deras uppgifter är inte minst att bevaka förändringar i lärosätenas omgivningsvillkor - vad som pågår på departementets och de överordnade myndigheternas nivå, förändringar inom forskningsfinansiering på lokal nivå, på riksnivå och inom EU.

Undersökningar av studenternas attityder, examensfrekvens och arbetsmarknadsframgångar är andra uppgifter för denna grupp. Det är data som ska tjäna som underlag för ledningens styrning av underordnade fakulteter och institutioner, deras storlek och inriktning.

Expansionen av tjänster som informatörer och kommunikatörer är tydligt länkade till den konkurrenssituation som lärosätena har att förhålla sig till. Deras uppdrag gäller inte bara att marknadsföra det egna lärosätet inför de studenter man hoppas kunna rekrytera. Hemsidor och villigheten att trumpeta ut de framgångar som lärosätets forskare haft är en del av kommunikatörernas varumärkesbyggande och synliggörande av den egna högskolan.

Ledningens ökande kontroll och styrning av den egna förvaltningen yttrar sig i en förtätning av kategorin chefer och direktörer. De centrala nivåernas styrning och kontroll av den nivå där lärosätenas reella verksamhet pågår, det vill säga inom institutioner och forskningscentrum, sker på flera olika sätt. Nya yrkesfunktioner som exempelvis högt kvalificerade, i regel disputerade, utbildningsledare har tillkommit.

Den grundläggande styrningen sker dock via budgetering och kontroll av de ekonomiska flödena. Det har under 2000-talet kommit till uttryck i ett tydligt stigande antal ekonomer, controllers och övrig ekonomihanterande personal. Dessa grupper har i stigande grad anrikats på nivåer ovanför institutionerna. 


\section{Administratörernas stigande utbildningsnivå}

I 1960-talets utredningar och riksdagsbeslut uttrycktes tydligt behovet av en serviceorganisation för att avlasta professorer (och med tiden också universitetslektorer) den växande mängd av administrativa uppgifter som följde i spåren av ett snabbt stigande antal studenter. Avsikten var att dessa lärare skulle kunna koncentrera sig på sina kärnuppgifter, forskning och undervisning.

I dag har situationen ändrats radikalt. En betydande del av administratörernas arbetsuppgifter består numera av att förse såväl den lokala ledningen ("rektor") som de överordnade styrningsorganen (UKÄ, departementet med flera) med underlag för deras styrning av verksamheten liksom kontroll av hur lärare och forskare sköter sina uppgifter, håller budgeten och hanterar en alltmer differentierad skara av studenter. De nya uppgifterna har inneburit en förskjutning inom kåren av administratörer från enklare serviceuppgifter till mer krävande kontrollerande och styrande arbetsuppgifter.

I föregående avsnitt dissekerade vi förändringen i den administrativa personalens yrkestitlar utifrån en statistik som redovisar alla anställda, oavsett om de arbetade heltid eller deltid. Vi visade där hur olika yrken och yrkestitlar ökat eller minskat i antal under perioden 200I-20I8, i flera fall dramatiskt.

I detta avsnitt ska vi analysera hur den administrativa personalens utbildningsnivå har ändrats. Vi har frågat oss om de innehållsliga förskjutningarna i administratörernas yrkesfunktioner har samspelat med en förändring av deras utbildningsnivå och i vilken utsträckning detta har lett till att universitets och högskolors verksamhetsstöd akademiserats under 2000-talet.

Vi har redan visat hur assistenter och kontorister (i regel med gymnasie- eller grundskoleutbildning) minskat kraftigt eller helt försvunnit medan högskoleutbildade och mer specialiserade yrkesgrupper har tillkommit i administratörskåren. Sådana yrkesförändringar förklarar en del av den stigande utbildningsnivån som vi kan se i materialet. 


\section{Förändringen $i$ administratörsgruppens utbildningsnivå} frän 2001 till 2018

Administratörernas utbildningsnivå har stigit mellan 2001 och 20I8, vilket framgår av tabellen nedan.

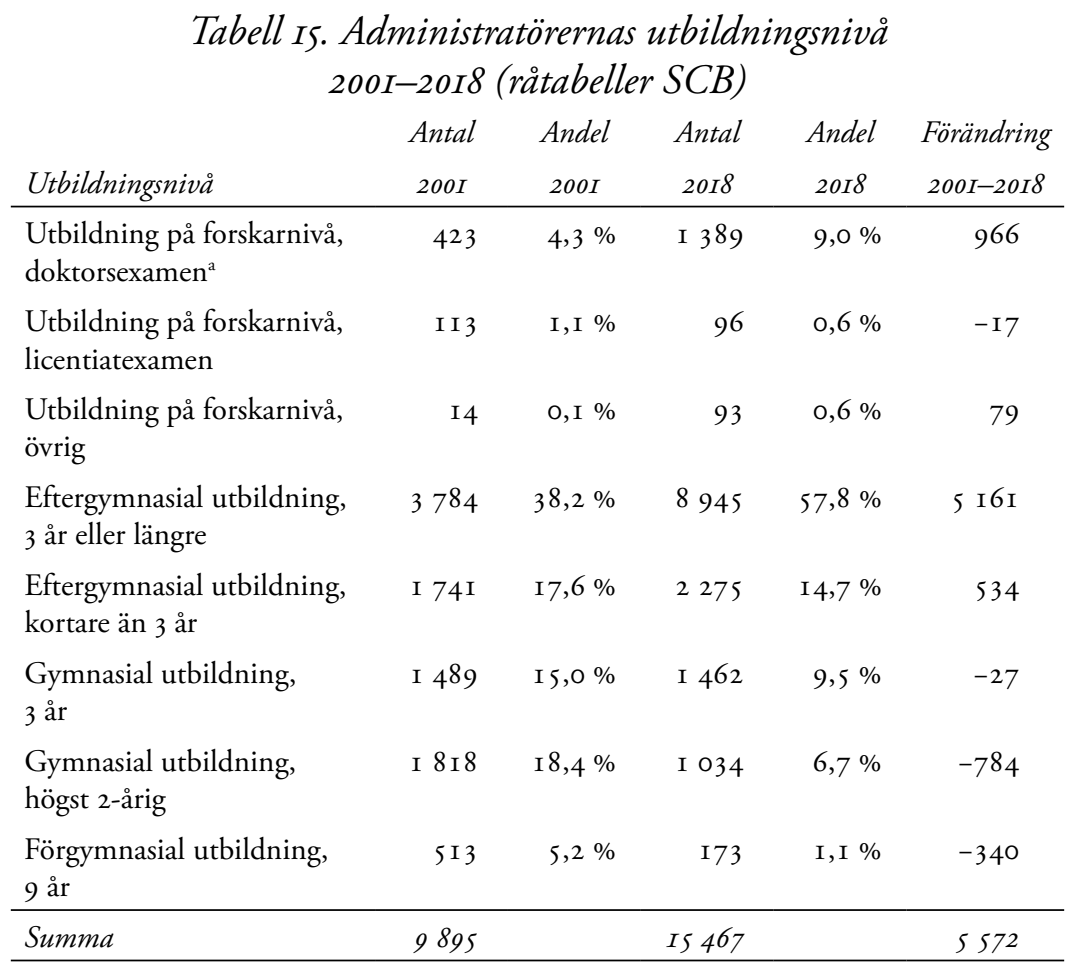

a. Här ingår ett mindre antal rektorer.

Två grupper sticker ut. Antalet administratörer som har minst tre års högskoleutbildning har ökat mycket markant $i$ antal och även som andel av gruppen som helhet, från 38,2 procent till 57,8 procent. Grupperna med kortare utbildning än så har minskat under 200o-talet. Den andra grupp som ökat markant är de som avlagt doktorsexamen (se vidare figur I nedan). 


\section{Figur I. Antalet disputerade administratörer} 200I-20I8 (råtabeller SCB)

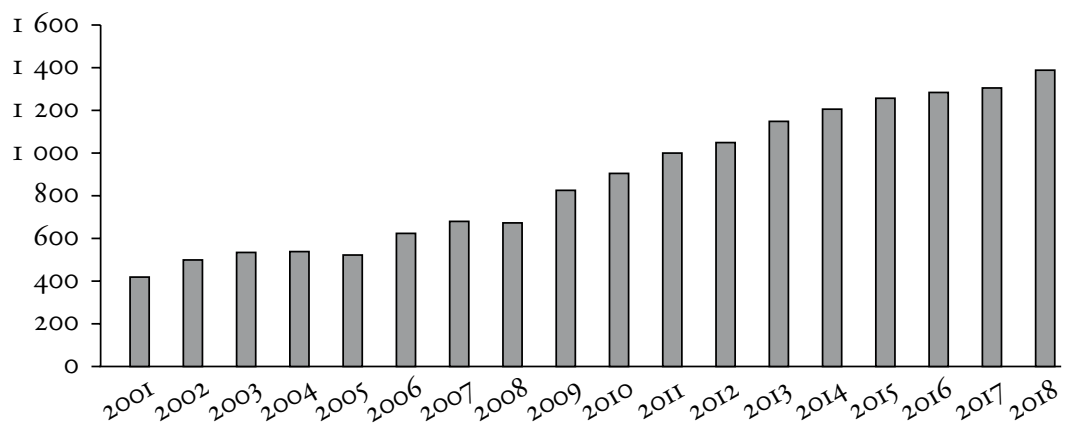

I dag är var elfte administratör inom universitet och högskolor disputerad. De allra flesta finns vid de gamla universiteten och fackhögskolorna. De administratörer som har disputerat, och där forskningsämne finns angivet, fanns till helt övervägande del -86 procent - vid de gamla universiteten och fackhögskolorna.

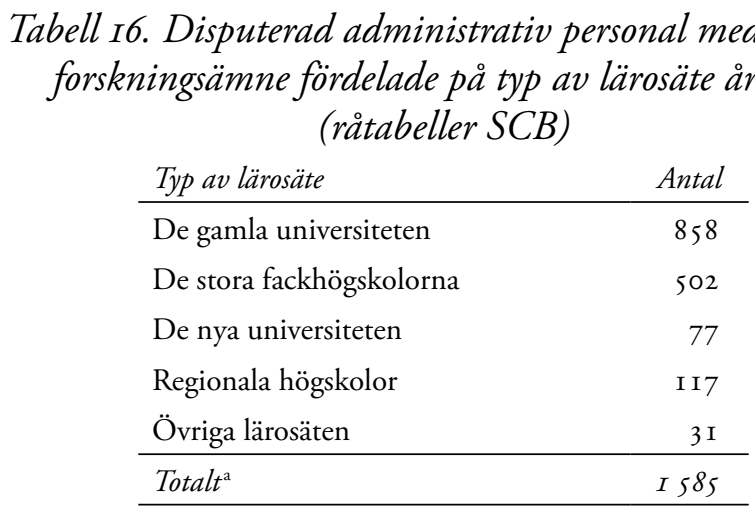

a. Häri ingår en del deltidsanställda och timavlönade personer, därav avvikelsen i relation till tabell is ovan.

De disputerade administratörerna har i många fall uppgifter som chefer för olika avdelningar och som ledare i olika administrativa och forskningskoordinerande sammanhang. De finns också i de nya, kvalificerade 
yrkesgrupper som vi redovisade i tabell II ovan, exempelvis som utredare och statistiker.

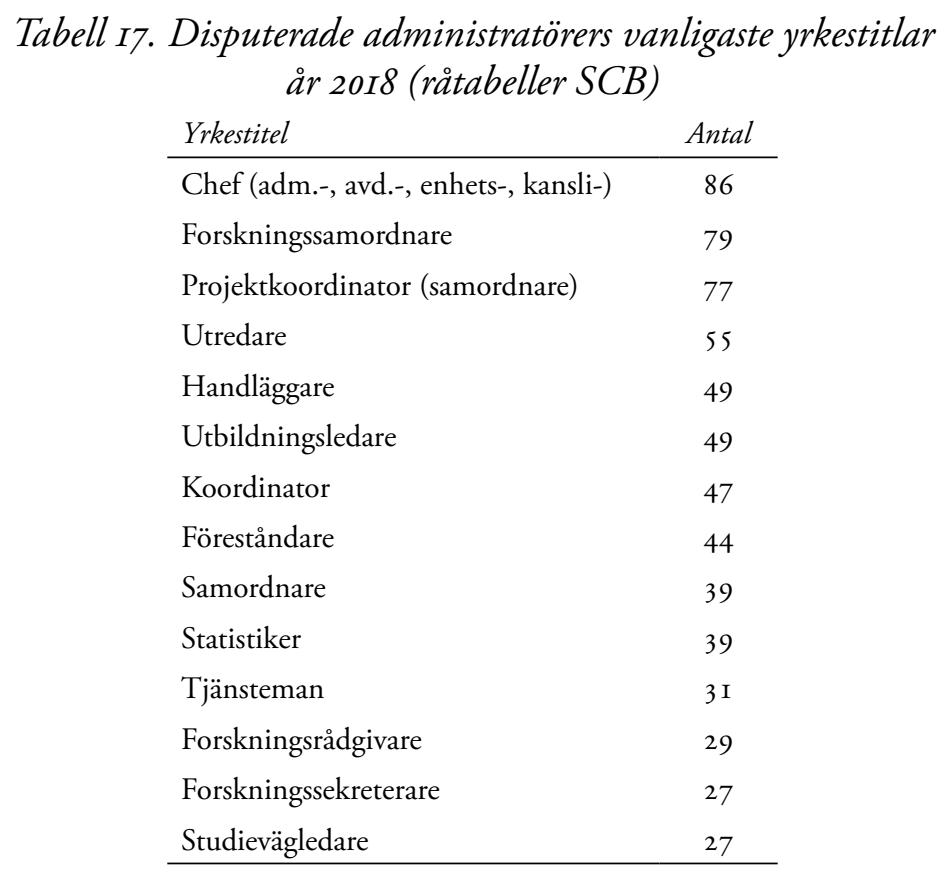

Not: De yrkestitlar som hade mer än 25 markeringar.

\section{Vad innebär akademiseringen av verksamhetsstödet?}

Den administrativa personalen vid universitet och högskolor har under 20oo-talet alltså i allt högre utsträckning kommit att ha akademisk utbildning. Antalet som disputerat har i det närmaste trefaldigats och antalet som avlagt en magister- eller masterexamen har likaledes ökat markant.

Vissa grupper har såväl akademiserats som ökat i absoluta tal. Det gäller exempelvis tre stora och snabbt växande yrkesgrupper: ekonomer, kommunikatörer och HR-personal. På den teknisk-administrativa sidan har antalet kvalificerade it-tekniker, systemvetare med flera ökat och inom biblioteken har antalet anställda med formell biblioteksutbildning 
blivit fler. Dessa akademiskt skolade yrkesgrupper är medvetna om sin egen kompetens och vill gärna kunna använda den för kvalificerade uppgifter inom ramen för sitt arbete. Och gärna för mer kvalificerade sysslor än dem de nu utför.

För flera av dessa grupper gäller också att de i dag i högre utsträckning arbetar tillsammans med kollegor med samma bakgrund och utbildning och de gör det i egna avdelningar och sektioner. Inom de flesta universitet och högskolor har olika administrativa och verksamhetsstödjande avdelningar koncentrerats till organisatoriska nivåer ovanför den akademiska basorganisationen, ämnesinstitutionerna. Det innebär att antalet yrkeskollegor som har liknande utbildningsbakgrund nu samlas i större enheter, enheter som därtill lyder under egna chefer och ledare, ofta med samma utbildnings- och yrkesbakgrund som personalen.

De sociala villkoren för dessa växande grupper inom universitets- och högskolesektorns administration, tekniska förvaltningar och bibliotek leder till att de nu fått bättre förutsättningar att gemensamt verka för att deras kompetens och expertis skall värderas och gälla inom deras egen räjong. Det blir tydligt om vi ställer denna nya situation i kontrast till vad som gällde för några decennier sedan. Då var många av dessa tjänstemän placerade i ämnesinstitutioner och prefekten var deras chef. De var utspridda på olika institutioner och inordnade i deras arbetsdelning. Det är en sak att vara forskningssekreterare som är nära knuten till ett lärarkollegium och en skara doktorander, en helt annan att vara anställd vid ett fakultetskansli, med en viss del av tjänsten förlagd till en institution, men där kollegorna på kansliet är den sociala miljö som gäller.

Det är stor skillnad på dessa situationer. I den första är administratören/ekonomen/forskningssekreteraren infogad i en mindre basorganisations arbetsdelning med dess enhetliga ledningsstruktur och inte minst dess lokala sociala miljö. Det var i denna miljö de deltog i institutionsresor, internat och fester. I den andra modellen existerar två parallella organisationstyper (den vetenskapliga och den administrativa), som bara knyts samman i toppen av högskoleorganisationen, antingen det nu är under dekanen eller under rektor.

En effekt av akademiseringen och betoningen av olika yrkesgruppers unika kompetens är att rekryteringen till universitetssektorns admi- 
nistrativa uppgifter och till dess bibliotek knyts allt närmare till, och reserveras för, de som har gått specifika utbildningar. Biblioteken får till exempel en allt större andel bibliotekarieutbildad personal, inte minst av dem som gått den linje vid biblioteksutbildningarna som är inriktad mot universitet och högskola.

Ökningen av antalet akademiskt utbildade administratörer och anrikningen av dem i större enheter och inom egna sektioner eller avdelningar ledda av chefer med samma bakgrund gör att universitetslärargruppen inte längre har något direktinflytande över deras arbetssituation och sociala miljö. Allt detta har lett till att stora grupper av administrativt anställda verkar i en organisatorisk kontext och social miljö där deras möjligheter att i större utsträckning kunna styra över sina egna arbetsuppgifter har ökat. Hit hör också ambitionen att kunna styra rekryteringen av nya kollegor. Ser vi här ett nytt slag av professionell ambition växa fram?

\section{"Mer utbildning är alltid bättre"}

För dem som själva arbetar som ledare, lärare och forskare inom universitet och högskolor är det lätt att acceptera systemets doxa, tron på att mer utbildning alltid är bra, ju längre desto bättre. Den självklarheten blir ett problem när man ska rekrytera till mindre kvalificerade tjänster inom en hierarkisk organisation av det slag som högskolor är.

Det är normalt inget problem när ICA-butiken ska anställa ny personal till kassorna eller lagret. Men när man inom högskolan använder utbildningsnivå som ett meriterande kriterium i sig för att rekrytera en person till en tjänst som till stor del består av rutinuppgifter blir det problem. När personen väl fått tjänsten kommer kravet på att få arbetsuppgifter i nivå med den kompetens (den utbildning) som hen har. Det kan vara rationellt ur individens synpunkt men inte alltid ur organisationens. ${ }^{35}$

35. Ett exempel kan illustrera hur detta utspelar sig på ett konkret mikroplan. En institution skulle i början av 2000-talet anställa en forskningssekreterare. Arbetsuppgifterna var tydligt specificerade. Däri ingick att bistå forskarämnets kollegium med olika uppgifter, att hjälpa doktoranderna med deras individuella studieplaner, att administrera kurserna på forskarutbildningen med mera. En nyutexaminerad jurist fick jobbet. Hen ansåg sig snabbt överkvalificerad för de viktiga men delvis rutinbetonade uppgifter som tjänstebeskrivningen innehöll. Det gjorde inte institutionens eller ämnets arbete och uppgifter lättare att genomföra. 


\section{Konsekvenser av administrationens akademisering}

Vilka effekter kan den högre utbildningsnivån i den administrativa personalen få? En betydande del av den genomsnittligt höjda utbildningsnivån inom gruppen av administratörer är en följd av att nya specialiserade yrkesgrupper och arbetsfunktioner har tillkommit. Dessa yrkesgrupper har stärkt systemets enheter och främst då dess ledningars kapacitet att navigera i den nya situation som lärosätena har att verka inom. Den mångfacetterade osäkerhet som konkurrensen om medel, personal och studenter skapat söker ledningarna hantera med mera kunskap om sina omgivningar och en starkare kontroll av lärosätenas organisation, budget och personal.

Kommer administratörernas ökade likställighet i termer av utbildningsnivå och arbetsfunktioner med delar av universitetslärargruppen att leda till en ökad betoning på karriär och till krav på mer utvecklande arbetsuppgifter? Ett sätt att beskriva denna förskjutning i arbetsuppgifter och den organisatoriska anrikningen av kvalificerade administratörer i egna enheter och sektioner är att se det som ett tecken på att kåren delvis professionaliseras.

I det professionella förhållningssättet finns en spänning mellan uppgiftstid och klocktid. Kravet på att fullgöra en uppgift kommer lätt i konflikt med "klocktiden", den tidsregim som karakteriserar lönearbetet. För en del av administratörerna, inte minst för dem som har en längre akademisk bakgrund, kan deras tidshabitus ha påverkats så att de närmar sig lärar- och forskargruppens "uppgiftstid”. Detta gäller exempelvis för grupper som utredare, utbildningsledare eller för dem som är prefekter och dekaner. Här löses det traditionella lönearbetets klocktid delvis upp.

En motsatt rörelse kan i dag skönjas inom lärar- och forskargruppen (se avsnitt 5 ovan). Den kan förstås som en reaktion mot en stigande belastning av administrativa uppgifter, särskilt toxiska sådana, vilket i sin tur är resultatet av en omförhandlad arbetsdelning, förorsakad av tekniska och organisatoriska förändringar. 


\section{Könsfördelningen inom administratörsgruppen}

Vid millenniets början var fyra av fem administratörer kvinnor. En stor andel var kontorister, sekreterare och assistenter. Merparten av denna kvinnliga biträdespersonal har försvunnit under 2000-talet. År 2018 hade andelen kvinnor inom gruppen administratörer sjunkit något, med 2,8 procentenheter. Fortfarande är universitetsadministrationen en kvinnodominerad arbetsmarknad.

Tabell I8. Antal män och kvinnor $i$ den administrativa personalen 2001 och 2018 (helàrsarbeten)

\begin{tabular}{lcc} 
Kön & 2001 & 2018 \\
\hline Kvinnor & $680 \mathrm{I}$ & 9407 \\
Män & $\mathrm{I} 8 \mathrm{I0}$ & 2930 \\
\hline Andel kvinnor & $79,0 \%$ & $76,2 \%$ \\
\hline
\end{tabular}

Källa: UKÄ, Universitet och högskolor. Årsrapport 2019.

Inom den snabbt växande gruppen av disputerade administratörer är kvinnornas andel lägre än i gruppen som helhet.

Tabell I9. Andel kvinnor och män av administrativ personal med
doktorsexamen 20I8 (råtabeller SCB)
\begin{tabular}{rrr} 
Utbildningsnivå & Män & Kvinnor \\
\hline Doktorsexamen & $43,3 \%$ & $56,7 \%$ \\
Ej forskarutbildad & $23,3 \%$ & $76,7 \%$ \\
\hline
\end{tabular}

Bland de disputerade administratörerna, de som vi kan anta har bäst villkor och störst inflytande, utgör männen en relativt stor andel. Men kvinnorna dominerar dock fortfarande även inom denna grupp.

\section{Störst ökning i de högsta utbildningsgrupperna}

Ser vi till utvecklingen mellan 200 o och 2018 visar det sig att kvinnorna har ökat sin relativa andel i de två snabbast tillväxande utbildningsgrupperna, de med en akademisk examen (minst 3 års högskoleutbildning) 
och de med doktorsexamen. Kvinnornas andel har därtill sjunkit inom grupper som har kortare utbildningar. Det betyder att deras andel av de mest kvalificerade arbetena inom högskolornas och universitetens administrativa apparater har ökat i en betydande grad under 2000-talet.

Tabell 20. Utbildningsnivå för kvinnor inom administrationen 200I-20I8 (rätabeller SCB)

\begin{tabular}{lccc} 
& $\begin{array}{c}\text { Andel } \\
\text { kvinnor }\end{array}$ & $\begin{array}{c}\text { Andel } \\
\text { kvinnor }\end{array}$ & $\begin{array}{c}\text { Förändring } \\
\text { Utbildningsnivå }\end{array}$ \\
\hline Samtliga utbildningsnivåer & $78,8 \%$ & $75,0 \%$ & $-3,8 \%$ \\
Förgymnasial utbildning, 9 år & $88,5 \%$ & $72,9 \%$ & - I 5,5\% \\
Gymnasial utbildning, högst 2-årig & $93,0 \%$ & $87,2 \%$ & $-5,8 \%$ \\
Gymnasial utbildning, 3 år & $89,2 \%$ & $85,3 \%$ & $-3,9 \%$ \\
Eftergymnasial utbildning, kortare än 3 år & $82,8 \%$ & $76,5 \%$ & $-6,3 \%$ \\
Eftergymnasial utbildning, 3 år eller längre & $69,9 \%$ & $74,4 \%$ & $4,6 \%$ \\
Utbildning på forskarnivå, doktorsexamen & $34,2 \%$ & $56,7 \%$ & $22,6 \%$ \\
Utbildning på forskarnivå, licentiatexamen & $44,7 \%$ & $56, \mathrm{I} \%$ & I I,4 \% \\
Utbildning på forskarnivå, övrig & $60,0 \%$ & $66,7 \%$ & $6,7 \%$ \\
\hline
\end{tabular}

Lärar- och forskargruppen är fortfarande tydligt mansdominerad, särskilt när vi tar tjänsternas hierarki i beaktande (ökande andel kvinnor när vi går från professor via lektor till adjunkt). Männens andel av administratörskåren växer långsamt och den är som störst i gruppens mest kvalificerade del, de som har avlagt doktorsexamen. Men det är viktigt att framhålla att kvinnorna under 2000-talet tydligt har ökat sin andel av de mest kvalificerade tjänsterna inom universitets- och högskoleadministrationernas alltmer välutbildade maskineri. 


\section{Universitetsadministratörer - en ny profession?}

I USA och Storbritannien spelar de ledande universitetsadministratörerna en central roll vid dessa länders lärosäten. I USA har de en egen professionell organisation, American Association of University Administrators (AAUA), som organiserar till exempel:

rektorer, dekaner, universitetsdirektörer, administrativa chefer, institutionsprefekter samt personer som arbetar inom en rad andra administrativa befattningar. ${ }^{36}$

I Storbritannien är den motsvarande organisationen för universitetens administratörer AUA, Association of University Administrators. AUA definierar sig som "professionssammanslutningen för ledare och administratörer inom den högre utbildningen". ${ }^{37}$

Både den amerikanska och den brittiska organisationen definierar sig uttryckligen som professionella organisationer, med en stark betoning på medlemmarnas utveckling inom yrket, gemensamma yrkesmässiga standarder etc.

Celia Whitchurch har i flera artiklar diskuterat denna del av administratörsskiktet som "blended professionals" ("blandprofessionella"). ${ }^{8}$ De grupper som det här gäller är dels akademiskt förankrade (via sin utbildning, exempelvis en doktorsexamen), dels ingår de i lärosätenas ledningsskikt eller återfinns i högskolesektorns centrala organ; för Sveriges del till exempel UKÄ och andra centrala myndigheter. Whitchurchs argument kan sammanfattas så här:

Är du yrkesverksam inom högre utbildning, med förvaltnings- och ledningsansvar? Då är du förmodligen en så kallad "blandprofessionell" [...]. Det vill säga: tekniskt sett är du en del av universitetsadministrationen (ditt yrkesliv styrs av regler och regleringar som gäller för den administrativa personalen), men du har kvalifikationer som liknar lärar- och forskargruppens och du agerar i förvaltnings- och ledarroller som går långt utöver rent byråkratiska uppgifter. ${ }^{39}$

36. Se http://www.aaua.org/.

37. Se https://aua.ac.uk/.

38. Whitchurch 2009.

39. Nastase 2013. 
Whitchurch har även använt det metaforiska begreppet "third space professionals" för att karakterisera en del av den administrativa personalen inom högskolesektorn och dess olika lärosäten..$^{40}$ Metaforen anger ett utrymme som markerar det som finns i mellanrummet mellan det offentliga maskineriet för styrning och finansiering och de enskilda lärosätena. Den betecknar för det andra den mellanställning som denna grupp av akademiker-i-förvaltningen intar. Gruppen är kognitivt besläktad med universitetslärare och forskare, samtidigt som den är funktionellt förankrad i lärosätenas förvaltnings- och ledningsapparater. För Sveriges del bör vi även räkna tjänstemännen, särskilt de disputerade, inom högskolesektorns centrala myndigheter (UKÄ med flera) till denna grupp.

\section{Konferenser och ledningsgruppsmöten}

Universitetslärare och forskare har specifika arenor för att presentera sin forskning och för att skapa vetenskapliga nätverk med mera i form av vetenskapliga konferenser. För de ledande skikten inom universitetsförvaltningarna sker motsvarande erfarenhetsutbyten och parallellisering av policyer och riktlinjer genom andra former av möten, nätverk och konferenser samt inom organisationen SUHF.

Det ledande akademiskt-administrativa skiktets organisatoriska och personella förtätning sker genom möten där dekaner plus kanslichefer träffas och diskuterar gemensamma problem, exempelvis när ekonomioch personalchefer möts tillsammans med representanter från UKÄ och Ekonomistyrningsverket.

På det lokala planet möts prefekter, dekaner och kanslichefer regelbundet med ledningsgruppen inklusive de ledande tjänstemännen. Detta ligger inbyggt i en hierarkisk linjestyrningsmodell, den modell som i dag präglar svenska universitet och högskolor.

\section{Från värnpliktsmodell till extern rekrytering av chefer}

Det finns flera exempel på att ledningsposter som hittills varit förtroendeposter - rektor, dekan, områdeschef, prefekt - nu professionaliseras i meningen att de blir en yrkeskarriär för sig. Länge sågs uppgifter som att vara prefekt eller dekan som en slags akademisk värnplikt. Nu har en

40. Whitchurch 2008. 
ledningskarriär etablerats där återvändo till laboratoriet, biblioteket eller katedern inte längre är det normala eller ens förväntade. Akademiska ledningsfunktioner frikopplas på så vis från de institutioner och fakulteter och de discipliner som de ska leda och styra över. Vid flera lärosäten sammanfaller detta med att den kollegiala styrmodellen marginaliseras eller helt enkelt monteras ner.

Här kan vi notera en process som förefaller kunna leda till ett mera självständigt skikt av professionella akademiska administratörer, och kanske också till framväxten av en ny typ av akademisk ledarskapsprofession. Ett exempel på detta är den "rundvandring" av rektorer som under 2000-talet skett vid våra lärosäten - från Malmö till Chalmers, från Växjö till Halmstad, från Skövde till KTH.

\section{Io. Från service till styrning och kontroll?}

\section{"New public management" inom högskolesektorn}

New public management (NPM) är den sammanfattande benämningen på en uppsättning av styrtekniker som kommit att prägla offentlig förvaltning i Sverige under de sista 25-30 åren. För universitetslärarprofessionen har det inneburit att man successivt och allt tydligare infogats i en styrnings-, kontroll- och belöningslogik som syftar till ökad "produktivitet" och "effektivitet". Det sker i linje med de mål som satts av utbildnings- och forskningspolitiken. Konkret operationaliseras den av de lokala universitets- och högskoleledningarna och deras förvaltningsmaskineri.

Inom universitet och högskolor utgör bibliometri och pedagogisk läroplansteori sektorsspecifika styrinstrument. De har här gifts ihop med de allmänt förekommande och överordnade företagsekonomiska styroch incitamentsmodellerna. Tillsammans bildar de dagens system för att systematiskt styra och kontrollera omfånget, inriktningen och kvaliteten på den undervisning och den forskning som universitetslärarna och övrig forskande personal utför.

Detta styrsystem är inramat av konkurrensen mellan lärosäten, fakulteter och forskargrupper om resurser och av den individualiserade incitamentslogiken. Vilka konsekvenser får detta kraftfulla styrsystem för 
universitetslärarnas förhållande till ledningarna och verksamhetsstödets ledande skikt?

\section{Ett styrande skikt $i$ vardande?}

Universitet och högskolor har i ökande utsträckning skapat utrymme för nya grupper av välutbildade tjänstemän. Dessa befolkar inte minst de många enheter inom verksamhetsstödet som styr, kontrollerar och kringgärdar kärnverksamheten och därmed också universitetslärarnas olika uppgifter.

Bör man se högskoleutbildade och främst då disputerade administratörer som en ny och separat yrkesgrupp som strävar efter en egen professionell nisch i linje med vad som sker i USA? En forskare som Whitchurch argumenterar för att dessa grupper ska ses som "third space professionals", som en särskild professionell kategori med samordning mellan forskning och administration som en viktig arbetsuppgift. Deras roll inom högskolevärlden kan förstås utifrån den förändrade situation som universitet och högskolor har att hantera - önskan om expansion ifråga om forskningens resurser, behovet att utveckla nya utbildningsprogram, strävan att profilera lärosätena så att de kan komma med i internationella nätverk. Inte minst är deras uppgift att öka och regissera samverkan med näringsliv och myndigheter, lokalt och nationellt. Men än så länge spelar de i första hand en viktig roll i lärosätesledningarnas styr- och kontrollsystem.

Men hur kan vi hävda att detta skikt har ökat i betydelse och omfång inom sektorn när antalet anställda som klassificeras som administratörer faktiskt bara har ökat i samma takt som den undervisande och forskande personalen?

Vi har i denna artikel visat att det har ägt rum en betydande och kvalitativt avgörande omskiftning inom kategorin administrativ personal vid universitet och högskolor. Samtidigt som nya funktioner och nya typer av personal har tillkommit har andra fasats ut; inte minst gäller det sekreterare och kontorspersonal på institutionsnivån. Nya administrativa avdelningar och enheter med inriktning mot styrning, kontroll och utvärdering har byggts ut inom alla lärosäten. Samtidigt kan vi se hur en mer precis incitamentsstyrning av de enskilda lärarnas och forskarnas arbete har vuxit fram, både lokalt, nationellt och på europeisk nivå. 
Det betyder att universitetsförvaltningarnas tyngdpunkt har förskjutits. De servicefunktioner inom den administrativa personalen som ligger nära lärare och forskare på institutionsnivå har kraftigt minskat samtidigt som nya personalgrupper har ökat ledningarnas styrnings- och kontrollkapacitet. ${ }^{4 \mathrm{I}}$

Den slutsats vi kan dra är att universitet och högskolor i ökande utsträckning har skapat utrymme för nya grupper av välutbildade tjänstemän, vilka befolkar en rad av de enheter som styr, kontrollerar, omger och kringgärdar universitetslärarnas verksamhet och arbetsvillkor. I Sverige har detta skikt av akademiskt utbildade specialister och chefer inom lärosätenas administration ännu inte formerat sig i en egen professionell organisation, likt vad som sedan länge finns i USA och Storbritannien. De utgör i dag viktiga delar av lärosätenas styr- och kontrollsystem, liksom i högskolesektorns styrsystem på nationell nivå. Detta skikt är av det skälet av stort intresse för såväl professions- som utbildningssociologer att beskriva och analysera.

\section{Tack}

Många är de som hjälpt oss under den tid vi har arbetat med denna artikel. Vi har fått hjälp med data från tjänstemän på UKÄ, Utbildningsdepartementet och UHR, och från anställda vid Sveriges Universitetslärarförbund (SULF). Vi vill särskilt tacka Angelina Nyström vid Statistiska centralbyrån som professionellt och effektivt har tagit fram de dataserier vi behövt.

Tidigare versioner av artikeln har vi presenterat vid Sociologdagarna i Lund den 7-9 mars 2018 och på seminarier inom forskningsprojektet SHEFOE vid Uppsala universitet. Tack till deltagarna vid dessa tillfällen, och särskilt till Mikael Börjesson och Agnete Vabø.

Vi har genom samtal och brev fătt viktiga uppslag från Gunnar Andersson, Stefan Bystedt, Gunnel Holm, Magnus Karlsson och Anders Kjellberg vid Lunds universitet och från Elin Funck, Ellinor Platzer, Inger Thörnqvist och Dino Viscovi vid Linnéuniversitetet. Karin Jonnergård

4I. Detta stämmer också väl med den bild som Agnete Vabø (2015) ger av situationen i Norge. Jämför också Ivarsson Westerberg (2020). 
arrangerade en givande diskussion kring vår text med administratörer vid Ekonomihögskolan i Lund.

Vi har tacksamt tagit tillvara de synpunkter och förslag som lämnats av de tre bedömare som tidskriften Arkiv bett om att kritiskt granska artikeln inför eventuell publicering.

\section{Referenser}

\section{Källor och opublicerade datamaterial}

JÄMIX 20I6, Nyckeltalsinstitutets jämställdhetsindex.

SCB, råtabeller för år 200I-20I8 (högskolans personal).

VR 20I4, "Bibliometriskt underlag för medelsfördelning", dnr 354-20I4-64II.

URL: https://www.vr.se/download/18.78Ifb755163605b8cd2Ib517/I529480567632/

Bibliometriskt+underlag+f $\% \mathrm{C}_{3} \% \mathrm{~B} 6 \mathrm{r}+$ medelsf\% $\mathrm{C}_{3} \% \mathrm{~B} 6 \mathrm{rdelning}+140512 . p d f(30$ april 2020)

\section{Offentligt tryck}

SOU 1963:9. Universitetens och högskolornas organisation och förvaltning. 1955 års universitetsutredning. Del VII.

SOU 1963:IO. Universitetens och högskolornas organisation och förvaltning. I955 års universitetsutredning. Del VII. Bihang: Universitetsväsendets organisation. Rapport av Statskontoret.

SOU I993:3. Ersättning för kvalitet och effektivitet. Utformning av ett nytt resurstilldelningssystem för grundläggande högskoleutbildning.

SOU 2015:92. Utvecklad ledning av universitet och högskolor. Betänkande av Ledningsutredningen.

UHR, Arsredovisning 2019.

UKÄ, Universitet och högskolor. Årsrapport 2019.

UKÄ, Årsredovisning 2019.

\section{Litteratur}

Agevall, Ola \& Gunnar Olofsson (2019a). "Den högre utbildningens professionella fält", i Thomas Brante, Kerstin Svensson \& Lennart G. Svensson (red.), Det professionella landskapets framväxt. Lund: Studentlitteratur.

Agevall, Ola \& Gunnar Olofsson (2019b). ”Universitetslärarna och den högre utbildningen", i Thomas Brante, Kerstin Svensson \& Lennart G. Svensson (red.), Ett professionellt landskap i förvandling. Lund: Studentlitteratur.

Althusser, Louis (1974). Philosophie et philosophie spontanée des savants (1967). Paris: François Maspero (dansk översättning Filosofi, ideologi og videnskap. En introduktion. Köpenhamn: Rhodos 1975). 
Bourdieu, Pierre, Jean-Claude Chamboredon \& Jean-Claude Passeron (1968). Le métier de sociologue. Livre I. Paris: Mouton (engelsk översättning The Craft of Sociology. Epistemological Preliminaries. Berlin: Walter de Gruyter 1991).

Friberg, Torbjörn (2015). Universitetslärare i förändring. En antropologisk studie av profession, utbildning och makt. Malmö: Universus Academic Press.

Fällman, Ulla-Kari (2007). Redovisning av indirekta kostnader vid universitet och högskolor. SUHF.

Hjerdt-Goscinski, Gunilla, Thaly Nilsson \& Hans Norman (1978). ”Från myndighetsanslag till ändamålsinriktade anslag”, i Stig Strömholm \& Torgny Nevéus (red.), Universitet $i$ utveckling. Uppsala universitet under Torgny Segerstedts rektorat 1955-1978. Uppsala: Almqvist \& Wiksell.

Ivarsson Westerberg, Anders (2020). "Administrationssamhället och förvaltningspolitiken - vad vet vi om förändringen av administrationen och dess orsaker?”, i Peter Ehn \& Göran Sundström (red.), Statlig förvaltningspolitik för 2020-talet. En forskningsantologi. Statskontoret.

Nastase, Pusa (2013). "The Position of 'Blended Professionals' in Higher Education", blogginlägg på EAIE blog, på hemsidan för European Association for International Education (EAIE), publiserad 24 maj 2013.

URL: https://www.eaie.org/blog/position-of-blended-professionals-in-highereducation/ (30 april 2020)

Olofsson, Gunnar (2006). "Universitetets två tidsordningar: klocktid och uppgiftstid", Universitetsläraren, $\mathrm{nr} 8$.

Ryegård, Åsa, Thomas Olsson \& Karin Apelgren (red.) (2010). Att belägga, bedöma och belöna pedagogisk skicklighet. Uppsala: Avdelningen för universitetspedagogisk utveckling (PU), Uppsala universitet.

Stigmar, Martin (2009). "Att utvecklas som universitetslärare", i Martin Stigmar (red.), Högskolepedagogik. Att vara professionell som lärare i högskolan. Stockholm: Liber.

Vabø, Agnete (2015). Nasjonale og internasjonale utviklingstrekk i høyere utdanning siste 30 år. Hvilke konsekvenser har disse hatt for administrative arbeidstakeres roller og arbeidsoppgaver? Föredrag vid Høgskolen i Oslo og Akershus I8 mars 2015.

Whitchurch, Celia (2008). "Shifting Identities and Blurring Boundaries: The Emergence of 'Third Space' Professionals in UK Higher Education", Higher Education Quarterly, volym 62, nr 4. DOI: https://doi.org/IO.IIII/j.I468-2273.2008.00387.x

Whitchurch, Celia (2009). "The Rise of the 'Blended Professional' in Higher Education: A Comparison between the United Kingdom, Australia and the United States", Higher Education, volym 58, nr 3. DOI: https://doi.org/I0.I007/sI0734-009-9202-4

Åmossa, Karin (2018). Systemfel i kunskapsfabriken. Stockholm: SULF. 


\section{Utbildningssociologiska böcker om högre utbildning från Arkiv förlag}

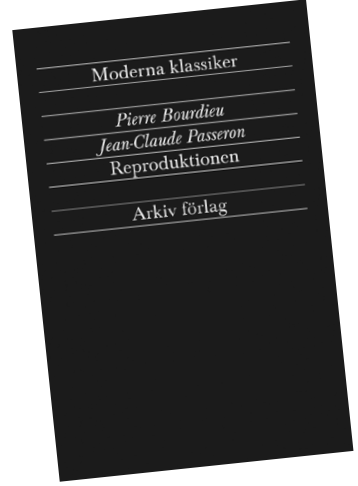

Pierre Bourdieu \&

Jean-Claude Passeron

Reproduktionen

Bidrag till en teori om utbildningssystemet

Bengt Gesser

Utbildning, jämlikhet, arbetsdelning

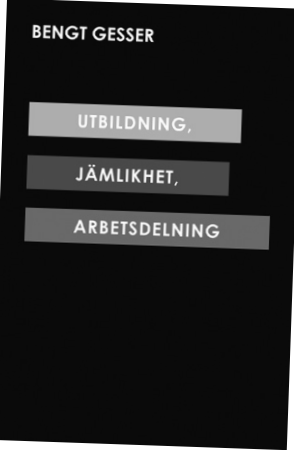

Magnus Persson Utbildningskontraktets villkor

Utbildningsförlopp på en förändrad

gymnasielärarutbildning

Eva Fasth \&

Gunnar Olofsson (red.)

Studenterna

Studenterna och deras utbildningar vid ett nytt universitet

och

deras

utbildningar

vid

ett nytt universitet

Gunnar Olofsson \&

Otto Petersson (red.)

Med sikte på profession

Akademiska yrkesutbildningar

vid ett nytt universitet

»Läs mer om böckerna på www.arkiv.nu» 